\title{
THE EFFECT OF FORMATION PROCESSES ON THE FREQUENCY OF PALAEOLITHIC CAVE SITES IN SEMI- ARID ZONES: INSIGHTS FROM KAZAKHSTAN.
}

\author{
Aristeidis Varis ${ }^{1,2}$, Christopher E. Miller ${ }^{2,3}, 4$, Patrick Cuthbertson ${ }^{1}$, Abay Namen ${ }^{1,5}$, Zhaken \\ Taimagambetov ${ }^{6}$, Radu lovita ${ }^{1,7}$ \\ ${ }^{1}$ Department of Early Prehistory and Quaternary Ecology, University of Tübingen, Tübingen, Germany \\ ${ }^{2}$ Institute for Archaeological Sciences (INA), University of Tübingen, Tübingen, Germany \\ ${ }^{3}$ Senckenberg Centre for Human Evolution and Paleoenvironment (HEP), University of Tübingen, Tübingen, Germany \\ ${ }^{4}$ SFF Centre for Early Sapiens Behaviour (SapienCE), University of Bergen, Norway \\ ${ }^{5}$ Department of Archaeology, Ethnology and Museology, Faculty of History, Archaeology and Ethnology, Al-Farabi \\ Kazakh National University, Almaty, Kazakhstan \\ ${ }^{6}$ National Museum of the Republic of Kazakhstan, Kazakhstan \\ ${ }^{7}$ Center for the Study of Human Origins, Department of Anthropology, New York University, New York, USA
}

*Corresponding author

E-mail: aristeidis.varis@uni-tuebingen.de

\section{EarthArXiv submission statement}

This manuscript is a non-peer reviewed preprint submitted to EarthArXiv. It has already been submitted to Geoarchaeology (Wiley Periodicals, LLC) journal for peer review.

\section{Abstract}

Central Asian caves with Palaeolithic deposits are few but they provide a rich record of human fossils and cultural assemblages that has been used to model Late Pleistocene hominin dispersals. However, previous research has not yet systematically evaluated the formation processes that influence the frequency of Palaeolithic cave sites in the region. To address this deficiency, we combined field survey and micromorphological analyses in the piedmont zone of south Kazakhstan. Here we present our preliminary results focusing on selected sites of the Qaratau mountains. Sediment cover varies among the surveyed caves and loess-like sediments dominate the cave sequences. The preservation of cave deposits is influenced by reworking of cave sediments within the caves but also by the broader erosional processes that shape semi-arid landscapes. Ultimately, deposits of potentially Pleistocene age are scarce. Our study provides new data in the geoarchaeologically neglected region of Central Asia and demonstrates that micromorphology has great analytical potential even within the limitations of rigorous survey projects. We 
outline some of the processes that influence the formation and preservation of cave deposits in Kazakhstan, as well as broader implications for the distribution of Palaeolithic cave sites in Central Asia and other semi-arid environments.

\section{Introduction}

Within the approximately four million square kilometers that span the five Central Asian Republics of Kazakhstan, Kyrgyzstan, Tajikistan, Turkmenistan, Uzbekistan, only 18 caves document Palaeolithic occupation (see Fig.1). These sites are located in the intermontane basins and river valleys that shape the foothills of the high altitude Central Asian mountain massifs. The Russian Altai, located at the northern fringes of Central Asia, has the highest frequency of Palaeolithic cave sites in the region, with a geographically restricted cluster found along the tributaries of major rivers. Further south, isolated Palaeolithic cave sites have been found in Kazakhstan, Kyrgyzstan, and Tajikistan, while the second cluster of sites is reported along the Alay mountains in Uzbekistan. The Palaeolithic occupation at the caves range from the Middle to the Upper Palaeolithic, and despite their low numbers, in many cases they have provided rich cultural assemblages and human remains (see ST1). Analysis of these palaeoanthropological remains has led to novel genetic discoveries regarding human evolution, such as the identification of the Denisovan hominin group (Krause et al., 2010; Reich et al., 2010; Slon et al., 2018). Building upon this record and in combination with data from open-air sites, various studies have tried to model the presence of hominins in the Central Asian landscape (Beeton et al., 2014; Glantz et al., 2018; Li et al., 2019; lovita et al., 2020). It seems that the foothills that connect the Central Asian mountains towards the West and the desert/steppe zones towards the East, form an Inner Asian Mountain Corridor (Frachetti, 2012) that may have served as a likely location of hominin refugia (Beeton et al., 2014; Glantz et al., 2018). Especially during glacial conditions, a 'northern' route along the foothills of the IAMC appears as the sole most likely scenario for hominin dispersal across Central Asia (Li et al., 2019; lovita et al., 2020). 
Even though these models provide important implications regarding the distribution of Palaeolithic sites in Central Asia, their accuracy is limited by the quality and quantity of the available dataset. In particular, the Russian Altai is the only well-studied area in the region, being the subject of multi-disciplinary research since the 1980s (Derevianko et al., 2018, p. 303). However, survey and excavation projects have been fewer south of the Altai, where the relative absence of systematic survey may have implications for the low distribution of cave sites (Fitzsimmons et al., 2017). We know little about the formation processes of the archaeological record in this region, since a high-resolution contextual methodology has been applied only on selected sites associated with hominin remains. In those cases, geoarchaeological approaches employing a microanalytical methodology (Mallol, Mentzer, \& Wrinn, 2009; Morley et al., 2019) or broadscale observations (Derevianko et al., 2018; Krivoshapkin et al., 2020) have significantly aided our understanding of geogenic deposition, anthropogenic impact, and local environmental change. These studies have broader archaeological importance since the analysis of cave sediments in arid to semi-arid environments, like Central Asia, is rather limited. Nevertheless, it should be noted that our picture for Late Pleistocene Central Asia is made up of only a few individual well-studied cases, extrapolated models, and limited knowledge of the processes that govern the archaeological record on a regional scale.

To change this picture, we require more field data to help us understand how the interaction between hominins and geomorphic environments shaped the unique Late Pleistocene archaeological record along the IAMC. In our recent paper (lovita et al., 2020), we presented preliminary results of the 2017-2019 survey in Kazakhstan and attempted to evaluate some taphonomic biases that influence the distribution and quality of archaeological sites in the region. Here, we build further upon that study to explore the occurrence and characteristics of cave sediments in South Kazakhstan. Firstly, we present statistics on the presence of sediment in caves and rockshelters based on the total number of features surveyed and testexcavated by our team. To assess the completeness of our dataset, we utilize observations on cave morphology to examine the potential erosion of pre-existing sediments. Secondly, we focus on the 
Qaratau mountains and combine field stratigraphy with micromorphology to explore the depositional processes operating at different cave sites within that range.

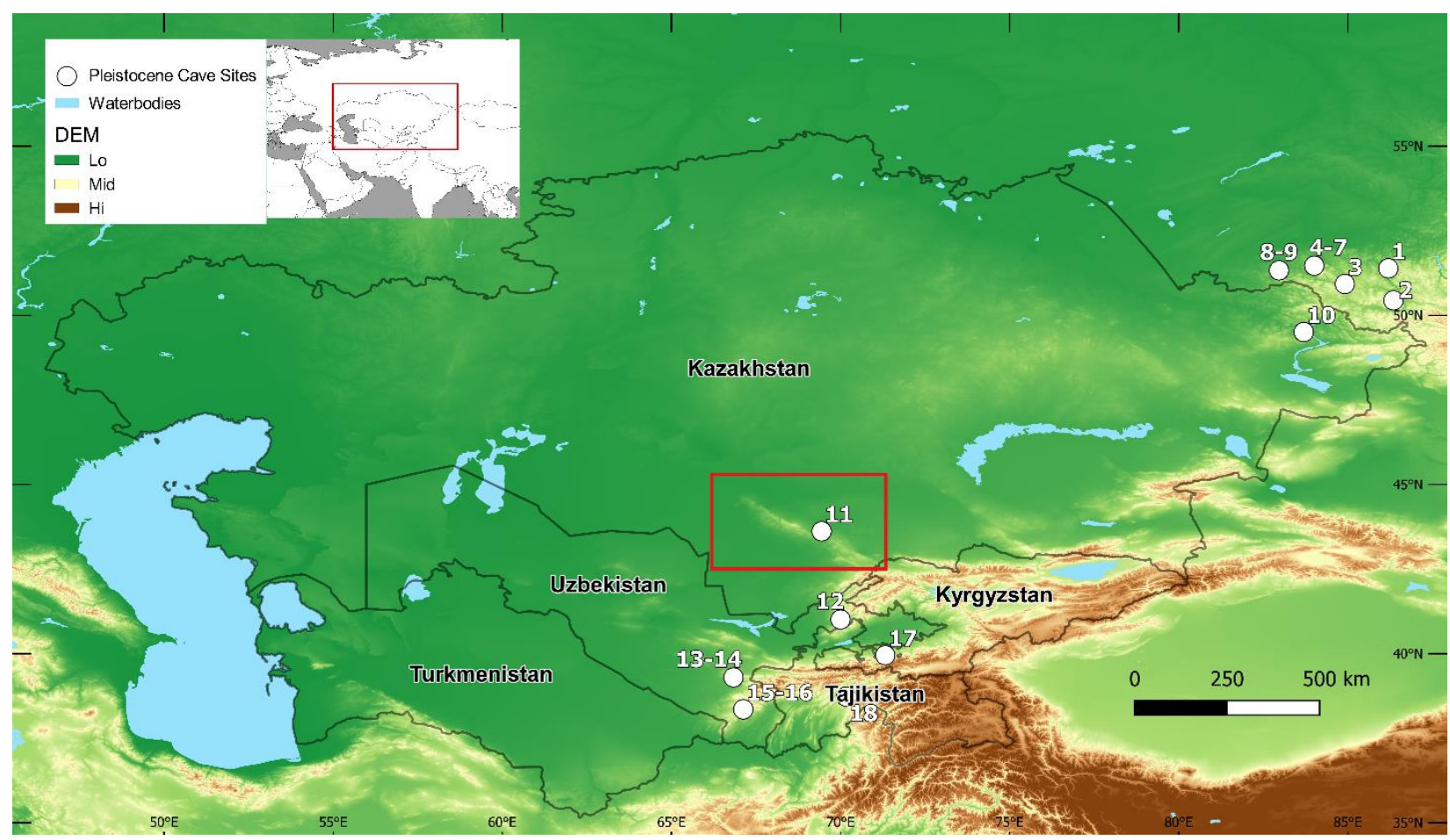

Fig. 1. Previously known Pleistocene archaeological cave sites in Central Asia. For references see ST1. Sites; 1) Byka cave complex.

2) Maloyalomanskaya. 3) Ust'-Kanskaya. 4) Iskra cave. 5) Okladnikov (Sibiryachikha). 6) Denisova. 7) Kaminnaya. 8) Chagyrskaya.

9) Strashnaya. 10) Bukhtarma cave. 11) Ushbas. 12) Obi-Rakhmat. 13) Anghilak. 14) Aman Kutan. 15) Amir-Temir. 16) Teshik-Tash.

17) Sel’ungur. 18) Ogzi-Kichik.

\subsection{The Qaratau mountains: geographic setting and geology}

The majority of our surveyed caves, including the caves presented in this study, are found in the Qaratau mountains (Fig. 2). The Qaratau mountain range is located in South Kazakhstan, delimited by the Syr Darya and Arys rivers to the West, Chu-Sarysu basin and Muyunkum desert to the East, South Turgay basin to the North and the Tian Shan Mountains to the South. It has a NW-SE trend and is divided into two ridges: the Lesser Qaratau in the southeast and the Greater Qaratau in the northwest. Overall, the Qaratau mountains constitute a Northern segment of the major Talas-Fergana fault (Burtman, 1980; Alexeiev et al., 2017), with their evolution tied to the broader patterns of Central Asian tectonics (e.g. Kirscher et al., 
2013).

Some of the oldest and most abundant rock types found in Qaratau include siliciclastic and volcanic rocks of Neoproterozoic age, as well as Middle and Upper Ordovician marine carbonates and granitoids. Towards the Middle Palaeozoic, volcanism and sedimentation in the region were generally associated with the passive margin development that contributed to the progressive amalgamation of the PalaeoKazakhstan continent (Biske, 2015). Regarding these changes, the formation of a carbonate platform from the Late Devonian until the Middle Carboniferous testifies to the presence of the Turkestan Ocean in the vicinity of Qaratau and marks a new period of carbonate deposition in the area. This carbonate sequence is about $4 \mathrm{~km}$ thick, outcrops frequently throughout the mountain range, and consists of depositional facies with diverse lithology (Cook et al., 2002). The geological picture of the area changed drastically after the Late Carboniferous, when major deformation events led to marine regression, termination of carbonate sedimentation, and uplift (Alexeiev et al., 2009). Continental accretion culminated during the Late Paleozoic, resulting in the closure of the Palaeo-Asian ocean and the formation of the Central Asian Orogenic Belt (Windley et al., 2007). Successive reactivations of the Talas-Fergana fault during the Mesozoic and Cenozoic induced additional deformation in the Qaratau. In the Jurassic, an elongated depression (Leontiev Graben) formed between the Greater and Lesser Qaratau, accumulating coal-bearing lacustrine and fluvial sediments (Allen, Alsop, \& Zhemchuzhnikov, 2001; Alexeiev et al., 2017). In the Cenozoic, the collision between India and Eurasia about 50 to $35 \mathrm{Ma}$ initiated substantial orogeny, with modern Tien Shan relief developing after 3 Ma (Buslov, Kokh, \& De Grave, 2008; Trifonov et al., 2008). The interplay between Quaternary climatic evolution and local neotectonics dramatically changed the environments of East Kazakhstan. Glaciations and increased aridification led to extensive deposition of glacial and aeolian sediments covering intermontane basins and their adjacent foothills (Aubekerov, 1993; Chlachula, 2010). 
In contrast to other parts of Central Asia and Kazakhstan, the major uplift in Qaratau enables the exposure of pre-Cenozoic structures that would otherwise be masked by recent sediments (Allen, Alsop, \& Zhemchuzhnikov, 2001, p. 84). This setting facilitates the survey of the karst-forming Paleozoic carbonate sequence and provides implications for the clustering of cave and rockshelters in this part of Kazakhstan.

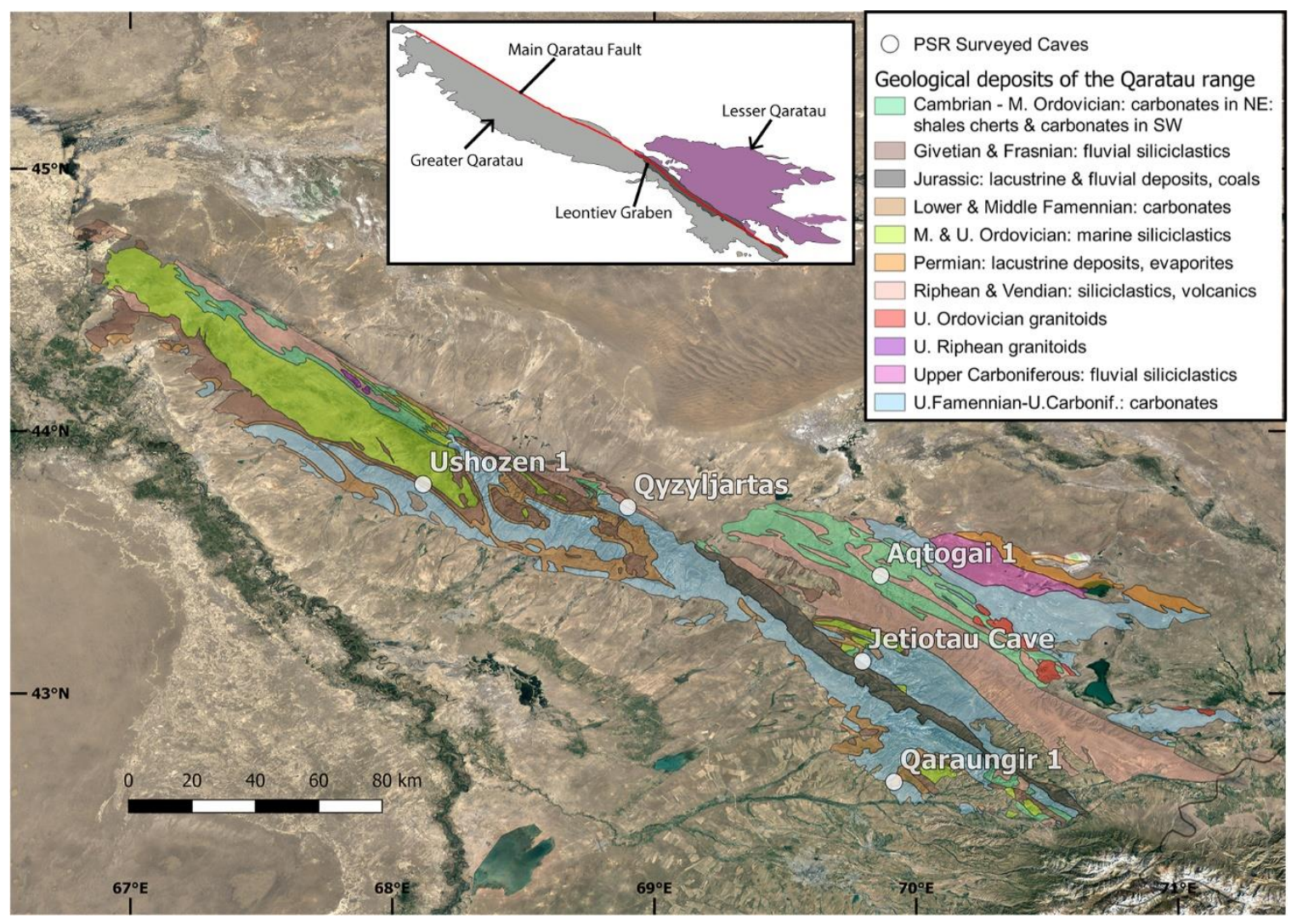

Figure 2. Geological map of the Qaratau mountain range with the sites analyzed in the text with micromorphology. The extent corresponds to the red bounding rectangle of Fig.1. Sketch map depicts the main tectonic structures mentioned in the text. Geological deposits adapted from Alexeiev et al. (2009; Fig. 1). Imagery (C2021 TerraMetrics, Karatau Range Kazakhstan @43.5235,69.2049, https://www.google.com/maps/.

\subsection{Micromorphology in a survey context}

Archaeological micromorphology is an established geoarchaeological technique that addresses a vast array of questions regarding the formation processes of deposits (Courty, Goldberg, \& Macphail, 1989; Macphail, 2014; Nicosia \& Stoops, 2017). It is often applied in well-documented sites and long-term 
excavation projects in the framework of a high-resolution approach that requires thorough sampling (e.g. Macphail, 1999; Karkanas \& Goldberg, 2010; Miller, 2015; Goldberg, McPherron, Dibble, \& Sandgathe, 2018), and often additional microcontextual techniques (e.g. Albert, Berna, \& Goldberg, 2012; Milek \& Roberts, 2013; Mentzer, 2014). As a survey project, we decided against this high-resolution approach since: 1) we aimed for a broad investigation of caves and rockshelters in our survey area, rather than focusing on a long campaign of excavating a single site; and 2) we could not apply an exhaustive range of analytical techniques because of logistical constraints on time in the field, as well as transport and storage during long survey campaigns. Instead, we used micromorphology selectively to gain a plethora of contextual information within promising sites, to interrogate difficult stratigraphic relationships, and to establish a connection between landscape and site-specific processes. While the micromorphological results presented here are not exhaustive and do not aim to reconstruct the whole range of formation processes operating at a given site, they provide preliminary insights into the characteristics of the excavated sequences by highlighting the dominant depositional factors that operate at these different localities.

\section{Methods}

\subsection{Survey methodology}

The caves and rockshelters presented here were surveyed and recorded during our recent fieldwork in Kazakhstan (lovita et al., 2020). The surveys were structured around a novel model-led approach (Cuthbertson et al., 2021) that used supervised and unsupervised landform classification, as well as the spatial extent of near-surface limestones and carbonates (CERCAMS; Seltmann, Shatov, \& Yakubchuk, 2014), to generate predictive mapping for areas of potential karstic feature formation. These models informed the targeted field survey, during which the features were identified. For the on-site recording of features we used an adapted version of the PaleoCore data structure (PaleoCore.org; Reed et al., 2015; Reed, Barr, \& Kappelman, 2018), and focused primarily on morphological attributes that were likely to be 
useful for further archaeological and geological investigations (e.g. sediment presence, cave morphology, speleothems).

\subsection{Sediment occurrence, stratigraphic documentation, and micromorphology}

A primary goal of our survey was to test the archaeological potential of caves in Kazakhstan. We used sediment thickness in individual caves as a guide to focus on prominent sites, based on the assumption that thicker cave sequences would have higher chances of preserving archaeological deposits or Pleistocene sediments. Furthermore, by documenting sediment characteristics across different caves, we built a regional dataset of cave sediment distribution that serves as a basis for exploring the depositional and erosional processes that influence the formation of the cave record.

To explore the potential erosion of pre-existing sediments in empty caves, we focused on the recording of specific morphological characteristics that could indicate erosional events in the interior and the exterior of karst features. Regarding the interior of karst features, we searched for past cave surface levels, remnant sediment pockets (unconsolidated or cemented), and evidence for the differential weathering of cave wall surfaces induced by sediment removal (O'Connor et al., 2017). Turning to the exterior of karst features, we investigated the adjacent topography to identify rockfall and debris accumulations (e.g., talus slopes) that could be associated with large-scale erosion of the features themselves.

For caves with sediment, we classified sediment thickness in both unexcavated and excavated features. In unexcavated features, we estimated sediment thickness as a minimum value from field observations of cave morphology, and where possible we used a dynamic cone penetrometer (Kessler Soils Engineering, Inc.; Model K100) to verify our assessments. For excavated caves, we documented sediment thickness based on older publications or from our new test trenches. Our classification scheme was heuristic and used three levels of sediment cover; caves with 'Minor' deposits $(<0.5 \mathrm{~m})$, 'Moderate' $(>0.5 \mathrm{~m})$ and 
'Significant' (>2m). We then used our data on sediment thickness to systematically test excavate promising caves, aiming to explore site specific depositional factors. For the documentation of the excavated sections, we defined lithostratigraphic units (LUs) following standard lithostratigraphic descriptions that focus on textural attributes and sedimentary structures. To facilitate comparison and synthesis between the deposits of different caves, the stratigraphic nomenclature is followed by the initials of each cave (e.g., LU J4 corresponds to the LU 4 from Jetiotau cave). In addition to macroscopic observations, we collected micromorphology samples from selected LUs. The micromorphological thin sections were subsequently divided into microstratigraphic units (MUs). Again, for comparative purposes, the MUs are named after LUs. For example, MU J4-1 corresponds to the first MU of LU J4.

\subsection{Thin section preparation procedure and analysis}

The micromorphology samples were encased in plaster and after extraction were wrapped with paper and packaging tape to ensure integrity during transport. Thin sections were produced in the Geoarchaeology Laboratory at the University of Tübingen and Terrascope Thin Section Slides. Initially, the samples were dried in the oven at $40 \mathrm{oC}$ and impregnated with a mixture of polyester resin, styrene and methylethylketone peroxide (MEKP) hardener under vacuum. After a period of around 20 days, the block samples reached the required hardness and were sliced into slabs with a rock saw after second heating. The thin section production procedure ended with the mounting of the slabs onto $6 \times 9 \mathrm{~cm}$ glass slides and their grinding to about $30 \mu \mathrm{m}$ thickness. For some samples, a third mounting or hand polishing was necessary to obtain the right thickness. The thin sections were initially scanned with a high-resolution flatbed scanner to be documented and examined macroscopically (Haaland et al., 2019). Afterwards, they were studied under a stereoscope (0.65 - 5x magnification), as well as, a petrographic microscope (20500x magnification) using plane-polarized light (PPL), cross-polarized light (XPL) and oblique incident light. Micromorphological descriptions follow the nomenclature and criteria proposed by Stoops (2003) and (Courty, Goldberg, \& Macphail, 1989). Thin sections were also examined under a fluorescent microscope 
equipped with the Zeiss Colibri system by using the $470 \mathrm{~nm}$ filter to test for phosphate and the $555 \mathrm{~nm}$ filter to test for organics.

\section{Results}

During the fieldwork seasons of 2017-2019, we surveyed a total of 95 caves and rockshelters (Table S1). 67 features are devoid of sediment and 28 have a varying degree of sediment cover. Out of the 28 features, eight caves had already been excavated in the past, we conducted test-excavations in ten caves in total, including five newly documented caves (Table 1). To get an overview of the characteristics of the sediment cover, we classify sediment thickness in both unexcavated and excavated features (Fig. 3A). Our findings demonstrate that only four features have 'Minor' deposits of $<0.5 \mathrm{~m}$, while most of the surveyed localities range between the 'Moderate' $(>0.5 \mathrm{~m})$ and 'Significant' $(>2 \mathrm{~m})$ sediment thickness categories with ten and 14 features, respectively. Caves with thicker sequences also tend to contain archaeological materials (Fig. 3B). Most of the archaeological materials recovered in our excavations appear to date to the Holocene and Pleistocene materials are scarce (Table 1).
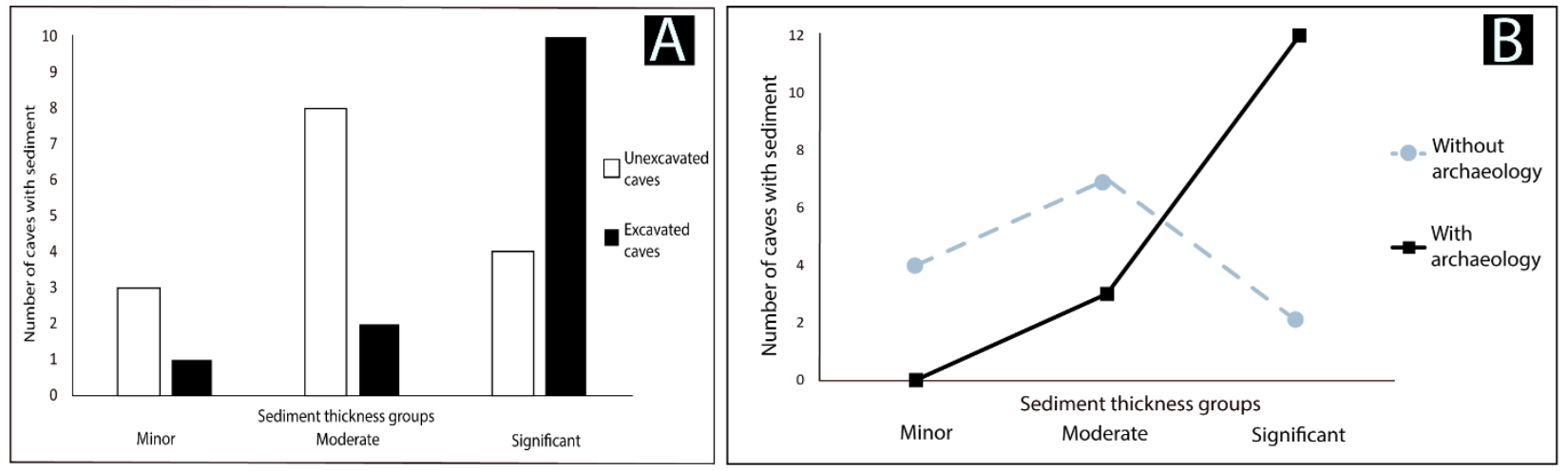

Fig. 3. Characteristics on the presence of sediments in caves and rockshelters surveyed by our team during the 2017-2019 seasons. A) Excavated and unexcavated features with sediment $(\mathrm{N}=28)$ grouped by sediment thickness. The sediment thickness classification is based on a combination of surface morphology, penetrometer measurements, and excavation data (where available). The sediment thickness groups are the following: Minor: $<0.5 \mathrm{~m}$; Moderate: $>0.5 \mathrm{~m}$; Significant: $>2 \mathrm{~m}$. B) Occurrence of archaeology among the different sediment thickness groups. Dotted line: features without archaeology. Solid line: features with Holocene or Pleistocene archaeology. See also Table 1. 


\begin{tabular}{|c|c|c|}
\hline Site name & Archaeology & Excavation data \\
\hline Aqtogai $1^{\dagger}$ & $\begin{array}{l}\text { Holocene } \\
\text { Pleistocene (?) }\end{array}$ & Shunkov, Taimagambetov, \& Kozlikin (2018); PSR, 2019 \\
\hline Hantagi 1 & Holocene & Z. Taimagambetov, personal communication \\
\hline Jetiotau $^{\dagger}$ & $\begin{array}{l}\text { Holocene (?) } \\
\text { Pleistocene (?) }\end{array}$ & PSR, 2018 \\
\hline Marsel Ungiri & - & PSR,2019 \\
\hline Mayatas & Holocene & Shunkov, Taimagambetov, \& Kozlikin (2018) \\
\hline Qaraungir $1^{\dagger}$ & Holocene & Taimagambetov \& Nokhrina (1998); PSR, 2019 \\
\hline Qyzyljartas $^{\dagger}$ & Pleistocene (?) & PSR, 2018 \\
\hline Temir 2 & $\begin{array}{l}\text { Holocene } \\
\text { Pleistocene (?) }\end{array}$ & PSR, 2019 \\
\hline Tuttybulaq 1 & $\begin{array}{l}\text { Holocene } \\
\text { Pleistocene (?) }\end{array}$ & Baytanaev et al. (2017, 2018); PSR, 2019 \\
\hline Tuttybulaq 2 & Holocene & Baytanaev et al. (2017); PSR, 2019 \\
\hline Uhbas 1 & Pleistocene & Alpysbaev, (1961); Grigoriev \& Volkov (1998); PSR, 2018 \\
\hline Ushozen $1^{\dagger}$ & Holocene & PSR, 2018 \\
\hline Yntaly 3 & Holocene & G. Iskakov, personal communication \\
\hline
\end{tabular}

+ Caves with micromorphological results presented in this paper.

Table 1. List of excavated caves in the Qaratau mountains. Note the abundance of Holocene archaeology among the excavated caves. Pleistocene sediments followed by (?) indicate potential chronology, since confirmation by absolute dating is pending. Excavations in most localities have not yet reached bedrock. For the locations of the caves see the supplementary material in (Cuthbertson et al., 2021).

Here we present our observations from the field and results of micromorphological analysis from five caves of the Qaratau mountains (Jetiotau, Qyzyljartas, Ushozen 1, Qaraungir 1, and Aqtogai 1; Figure 2, Table 1). We selected these five caves since their diverse sequences provide an overview of the major processes that seem to influence the formation of cave sites in the region.

\subsection{Jetiotau}

The Jetiotau cave is located approx. $2 \mathrm{~km}$ north-east from the Janatalap village of the Baidibek district, Turkestan region. It is formed on Lower Carboniferous (Tournaisian) carbonates at the South Western part of the lesser Qaratau, adjacent to the fault zone forming the Leontiev graben. It has a NW-SE orientation 
and a tube-shaped morphology consisting of a single $30 \mathrm{~m}$ long passage with a maximum roof height of approximately $7 \mathrm{~m}$.

\subsubsection{Stratigraphic overview}

In Jetiotau, we excavated a $3 \times 1 \mathrm{~m}$ test trench at the entrance area of the cave, exposing a stratigraphic sequence of $2.12 \mathrm{~m}$ without reaching bedrock (Table A1). The excavated deposits are generally brown to light olive brown with a silty clay to clay loam texture, while layer boundaries are mostly wavy and occasionally sharp. Angular limestone roof-spall clasts are the predominant inclusion present and mainly demonstrate random distribution and sorting. However, their frequency and size range vary, with more clasts occurring in LU J3 and LU J5. Although bone and charcoal fragments were found in low quantities scattered among different LUs, artifacts such as pottery or lithic tools were absent. Nevertheless, the well-defined transitions between clast-rich and clast-poor deposits at Jetiotau warrant further investigation since they may reflect changes in sedimentary input or different formation processes.

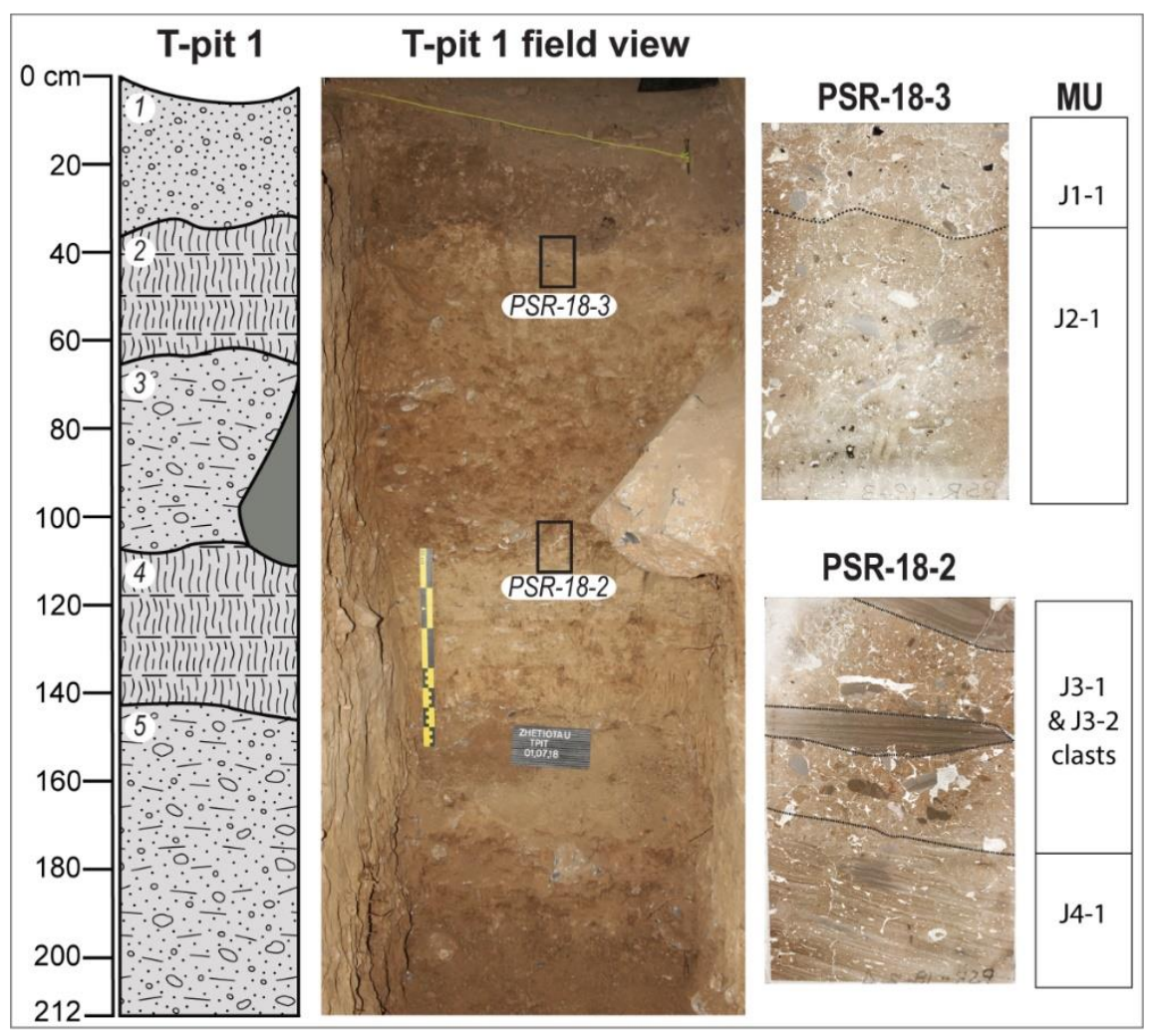


Figure 4. Stratigraphy and micromorphology in Jetiotau cave. Circled numbers indicate lithostratigraphic units: LU J1) clay loam; LU J2) silty clay loam; LU J3) clay loam; LU J4) silty clay; LU J5) clay loam; Black frames show the location of micromorphological samples accompanied by a scan of the thin section (PPL) and MU classification.

\subsubsection{Micromorphology}

Two micromorphology samples were collected from the northern section of the test trench. Sample PSR18-2 covers the contacts between LUs J3 and J4 while PSR-18-3 covers the contact between LUs J1 and J2. MU J4-1 comprises a laminated structure at the basal part of sample PSR-18-2 (Fig.4 and Fig. 5A) that demonstrates the effects of water action in the formation of the upper part of LU J4. This deposit mainly consists of micrite with the addition of well sorted silt, sand-sized quartz and mica grains in the coarser laminae. The fluctuating composition of the laminae is indicative of sheetwash processes (Karkanas \& Goldberg, 2018), while the parallel to sub-parallel orientation of mica grains (see Fig. 5B) also suggests deposition in a low energy water-lain environment (Mücher \& Ploey, 1977). Nevertheless, water flow was not constant during the formation of the laminated sequence. Phases of non-saturation are evidenced by the presence of intrusive yellowish-brown dusty clay coatings, burrows and elongated planar voids likely associated with cycles of wetting and drying.

MU J3-1 is a coarse and heterogeneous deposit overlying MU J4-1. It covers the rest of sample PSR-18-2 and correlates with the clast-rich LU J3. Under the microscope, this deposit is indeed clast-supported and comprised primarily of poorly sorted and randomly distributed clasts. The geogenic coarse material consists of limestone fragments, sand-sized mica, quartz and laminated clasts that constitute the most abundant aggregate. Some of the laminated clasts show similarities to MU J4-,1 while others have a more microsparitic texture. In both cases, they represent remobilized material originating from within the cave. Other components include limestone fragments, sand-sized mica and quartz. The coarse material shows a moderately expressed parallel to oblique orientation (Fig. 5C). In terms of biogenic inclusions, we recorded phosphatized pellets, carnivore coprolites and a few bone fragments (Fig. 14A). Lastly, it is also important 
to note the weakly developed fabric deformation features identified by the preferred concentration and orientation of elongated mica particles (Fig. 5E, 5F). These fabric features resemble the galaxy microdeformation structures described by Karkanas (2019). Based on the inclined geometry, unsorted sediment, the preferential concentration of coarse clasts and the presence of vesicles and galaxy structures, we interpret MU J3-1 as a relatively fluid debris flow (Karkanas \& Goldberg, 2018). The pre-existing inclined surface of LU J4 could provide the necessary angle for the development of a debris flow. Additionally, slumped laminated clasts (Fig. 5C) imply that a certain level of steepness and topographic variation most probably also characterized the geometry of sediments deeper into the cave.

MU J2-1 has a similar groundmass with MU J3-1 but appears more sorted and with different proportions of coarse components. In comparison with MU J3-1, MU J2-1 also contains charcoal fragments and has a more granular microstructure. Overall, the micromass of MU J3-1 appears to be more phosphatic and isotropic in XPL. In places, the phosphatization is accompanied by de-calcification judging by the absence of a crystallitic b-fabric and the removal of calcite in altered limestone clasts. However, in contrast to this de-calcified matrix, we observed many calcitic-crystallitic aggregates, as well as bone fragments heavily cemented by calcite (Fig. 5D). The great variation of post-depositional processes (de-calcified versus calcified components) in the same deposit constitutes a strong indication that MU J3-1 represents a mixture of different sediment sources.

MU J1-1 is a moderately sorted deposit with sand-sized charcoal and bone fragments that comprises the uppermost part of the sequence, corresponding to LU J1 and modern cave use. It has a similar fabric with MU J2-1. Granular microstructure at the top part of LU J1 and high frequency of channel voids demonstrate extensive bioturbation. 


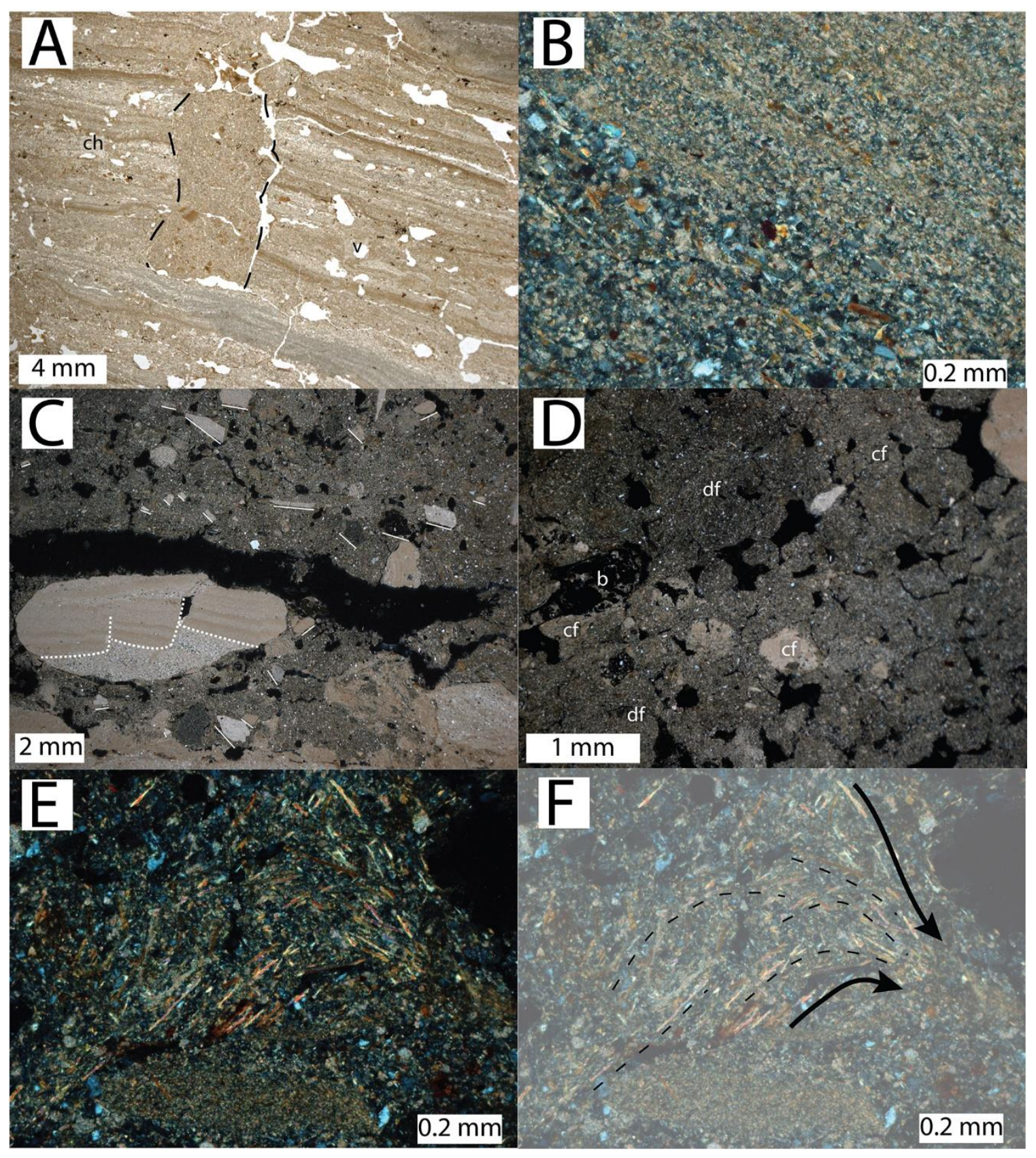

Figure 5. Microphotographs from Jetiotau cave. A) MU J4-1; Note laminated bedding dipping towards SW and complex microstructure consisting of vesicles (v) and channels (ch). Dotted lines outline a burrow breaking through laminae; PPL. B) MU J4-1 laminae. Note oblique orientation of mica grains following the inclination of the deposit and grading; XPL. C) MU J3-1; Note oblique to horizontal orientation towards the SW for the majority of coarse sand and gravel-sized clasts (white lines). White dotted lines indicate slumping of a laminated clast; XPL. D) MU J2-1; Mixing of calcitic crystallitic aggregates and matrix (cf) with decalcified and phosphatized (df) b-fabric. A partially cemented bone fragment (b) is also present; XPL. E and F) MU J3-1; 
Photomicrograph and sketch of a rotational micro-deformation feature showing preferential distribution, orientation and alignment of mica particles. Dotted and solid lines indicate general flow direction; XPL

\subsection{Qyzyljartas}

The Qyzyljartas cave is located at the north-eastern foothills of the Greater Qaratau range, about $10 \mathrm{~km}$ south-west of the Sozaq town. It is formed at the top of a steep sandstone outcrop (Fig. 3D), while the feature itself has three openings, two of which join together to create a long, funnel-like cave, open at two sides. Two sloped passageways are oriented southwest and south respectively.

\subsubsection{Stratigraphic overview}

Our investigations focused on the southwest passageway, where we excavated Test-pit E1 (1.5x1.5m, $85 \mathrm{~cm}$ deep) at the top of the slope, near the upper opening, and Test-pit E2 ( $2 \times 1 \mathrm{~m}, 1.5 \mathrm{~m}$ deep) at the bottom of the slope, near the opening at the face of the cliff. We exposed bedrock only in test-pit E2. The recorded sequences share common lithostratigraphic attributes and are generally correlated (Fig. 6). Only the lowermost units from each test-pit (LU Q4 and LU Q5) are not in a direct stratigraphic association, most probably due to the confined excavation area. Despite this difference, all layers dip towards the south following the inclination of the modern cave surface and have a homogeneous red to reddish-brown appearance. Based on structure, LUs alternate between loose clast-supported deposits dominated by fine sand-sized gravels, and compacted matrix-supported deposits with a massive clay texture. LU Q3 differentiates from the rest of the sequence as it includes grayish-blueish redox depleted horizons formed by settling of water (pseudogleying). Overall, the exposed stratigraphic sequence is entirely composed of geogenic components, with the complete absence of biogenic material, such as bone. A single lithic artifact (chert flake) of indeterminate industry was also recovered during section cleaning of test-pit E1 but its stratigraphic location is unknown. Despite the minimal archaeology, the sequence at Qyzyljartas demonstrates a distinct case study for the impact of past fluvial dynamics for the development of pseudokarstic features in semi-arid Kazakhstan (see also lovita et al., 2020, p. 123). 


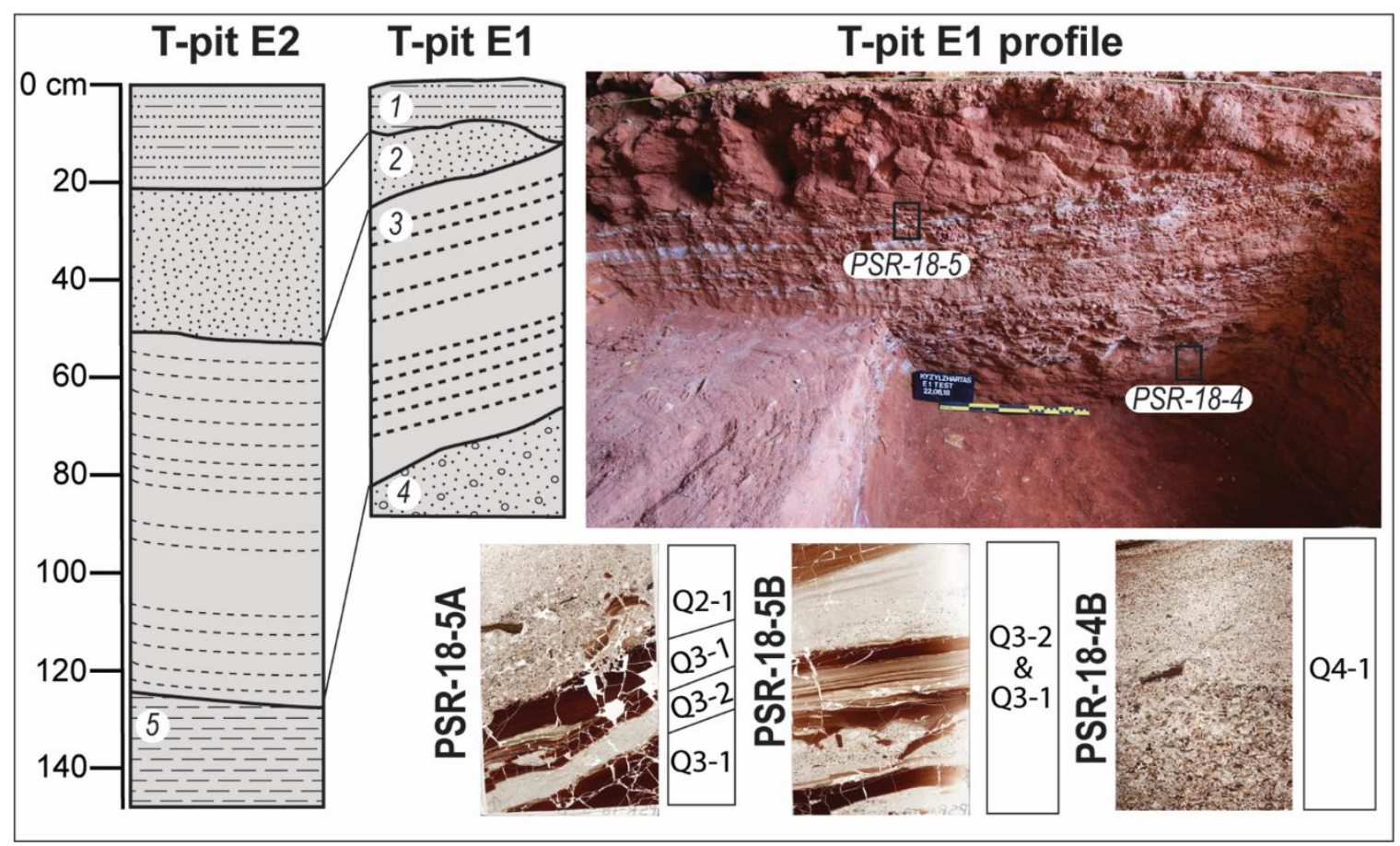

Figure 6. Stratigraphy and micromorphology in Qyzyljartas cave. Circled numbers indicate lithostratigraphic units: LU Q1) sandy silt loam; LU Q2) sandy loam; LU Q3) pseudogleyed interbedded silty/clayey beds; LU Q4) loamy sand; LU Q5) compacted clay; Black frames show the location of micromorphological samples accompanied by a scan of the thin section (PPL) and MU classification. LU 3 also is comprised of characteristic sandy and clayey interbedded deposits that are classified as MU types Q3-1 and Q3-2 respectively.

\subsubsection{Micromorphology}

MU Q2 is a clast-supported and poorly sorted deposit, primarily composed of rounded quartz (Fig.7A). Sandstone and organic shale rock fragments are common and are probably the source of the high quartz and organic-rich content observed under thin section. The presence of large-sized and rounded coarse material demonstrates high energy water action and long transport distances. Additionally, the inclusion of rip-up clasts that have the same clayey fabric as the underlying unit (MU Q3-1), demonstrate that water action also resulted in the erosion of adjacent sediments (Fig. 7A).

The interbedded layers that constitute LU Q3 can be classified into two main MU types. MU type Q3-1 consists of matrix-supported reddish to dark reddish silty clay layers with high organic content and massive 
structure (Fig. 7B). MU type Q3-2 are clast supported layers consisting of abundant quartz grains and are generally devoid of clay (Fig.7B). Except for quartz, MU type Q3-2 includes rip-up clasts of MU type Q3-1, indicating that their deposition involved the erosion of the underlying surface. They exhibit either a normal or reverse grading and they are generally thicker than MU type Q3-1. Slight changes in sedimentation patterns resulted in interlaminations and variation in grain sizes in both MU Q3-1 and Q3-2 types.

MU Q4 corresponds to the upper part of LU Q4 excavated in test-pit E1. The coarse material is dominated by coarse and sub-rounded quartz grains and demonstrates normal grading (Fig. 6, thin section scan PSR18-4B). It consists of similar fabric units as MU Q2-1 but has higher abundance of interstitial clay.

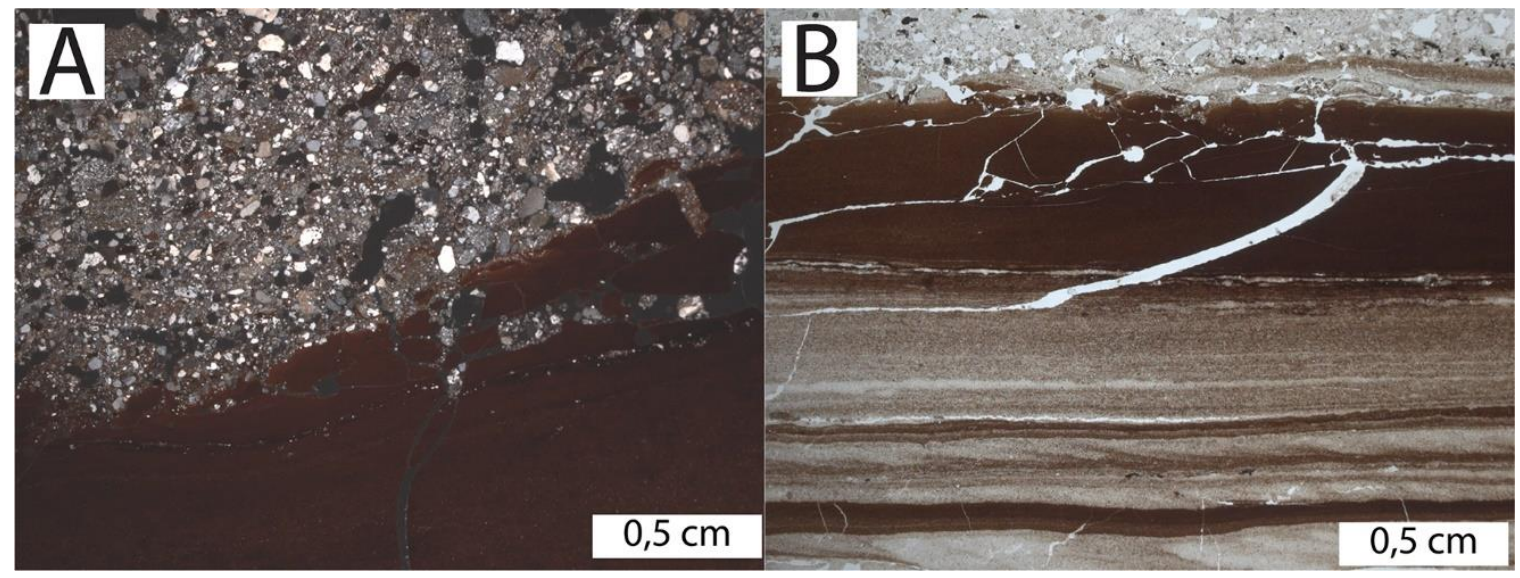

Figure 7. Microphotographs from Qyzyljhartas. A) Sharp and probably erosional boundary between MU Q2-1 and MU Q3-1; XPL.

B) Interbedded MU type Q3-1 (silty clay) and Q3-2 (sand) layers; PPL.

\subsection{Ushozen 1}

Ushozen 1 is a cave located $c a .10 \mathrm{~km}$ northwest of the Babaiqorgan village, Turkestan region, on the eastern bank of the homonymous Ushozen river. It is formed on Lower Devonian carbonates of the Aman formation at the nothwestern part of the Greater Qaratau. The cave is composed of a single chamber, approximately $7 \times 8 \mathrm{~m}$.

\subsubsection{Stratigraphy overview}


Our test trench at Ushozen 1 reached a maximum depth of $\sim 60 \mathrm{~cm}$, exposing scarce Holocene archaeological material at the top of the sequence but no dense cultural deposits. The LU's have a sandy silt texture, which becomes progressively more clayey and compacted towards the bedrock. The frequency of coarse clasts is generally low, except for LU U3, where abundant manganese oxide concretions and crusts were recorded directly above the bedrock. We hypothesize that these features have formed as nodules in the parent rock and that they are not pedogenic. Overall, textural attributes suggest that the settling of windblown material plays a major role in the accumulation of sediment in this cave.

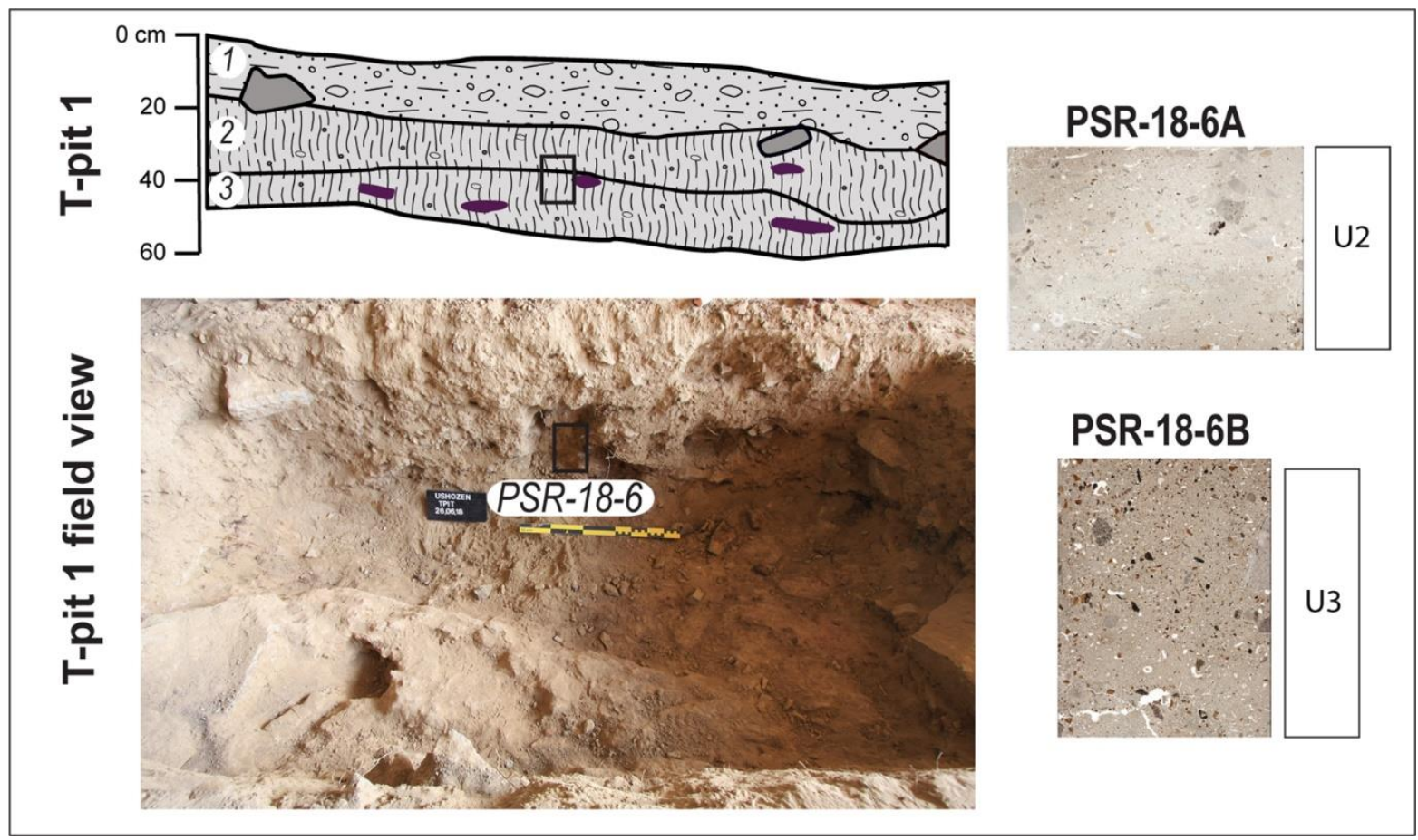

Fig. 8. Stratigraphy and micromorphology in Ushozen 1 cave. Circled numbers indicate lithostratigraphic units: LU U1) sandy loam; LU U2) sandy silt loam; LU U3) sandy clay loam. Black frames show the location of micromorphological samples accompanied by a scan of the thin section and MU classification.

\subsubsection{Micromorphology}

Micromorphology sample PSR-18-6 was collected from the Eastern section of the test trench (PSR-18-6) covering the contact between LUs U2 and U3 (Fig. 8). MU U2 and MU U3 show a bimodal distribution 
comprised mainly of coarse manganese oxide nodules, silty clay clasts associated with reworked endokarstic sediments (e.g. Goldberg, Berna, \& Chazan, 2015, p. 623) , and rock fragments in a finer loessdominated matrix (Fig. 9A). MU U3 has a more closely packed texture in comparison to MU U2 and is more bioturbated (Fig. 9B and 9C). In contrast to MU U3, MU U2 also contains rounded soil aggregates that are sometimes phosphatized (compare Fig. 9D with Fig. 14B) and randomly distributed dung spherulites probably associated with degraded dung deposits (Fig. 9D). The homogeneous loess-matrix in both MUs demonstrates that continuous aeolian processes plays a major role in the accumulation of sediment in this cave. The soil aggregates were most probably transported to the cave by anthropogenic activity (e.g., Goldberg et al., 2009), since the absence of upslope soil cover excludes the possibility of colluvial input. Nevertheless, the phosphatized soil aggregates provide a proxy of prior burial and remobilization in the cave environment, indicating some degree of reworking in the overall 'primary' loess matrix.

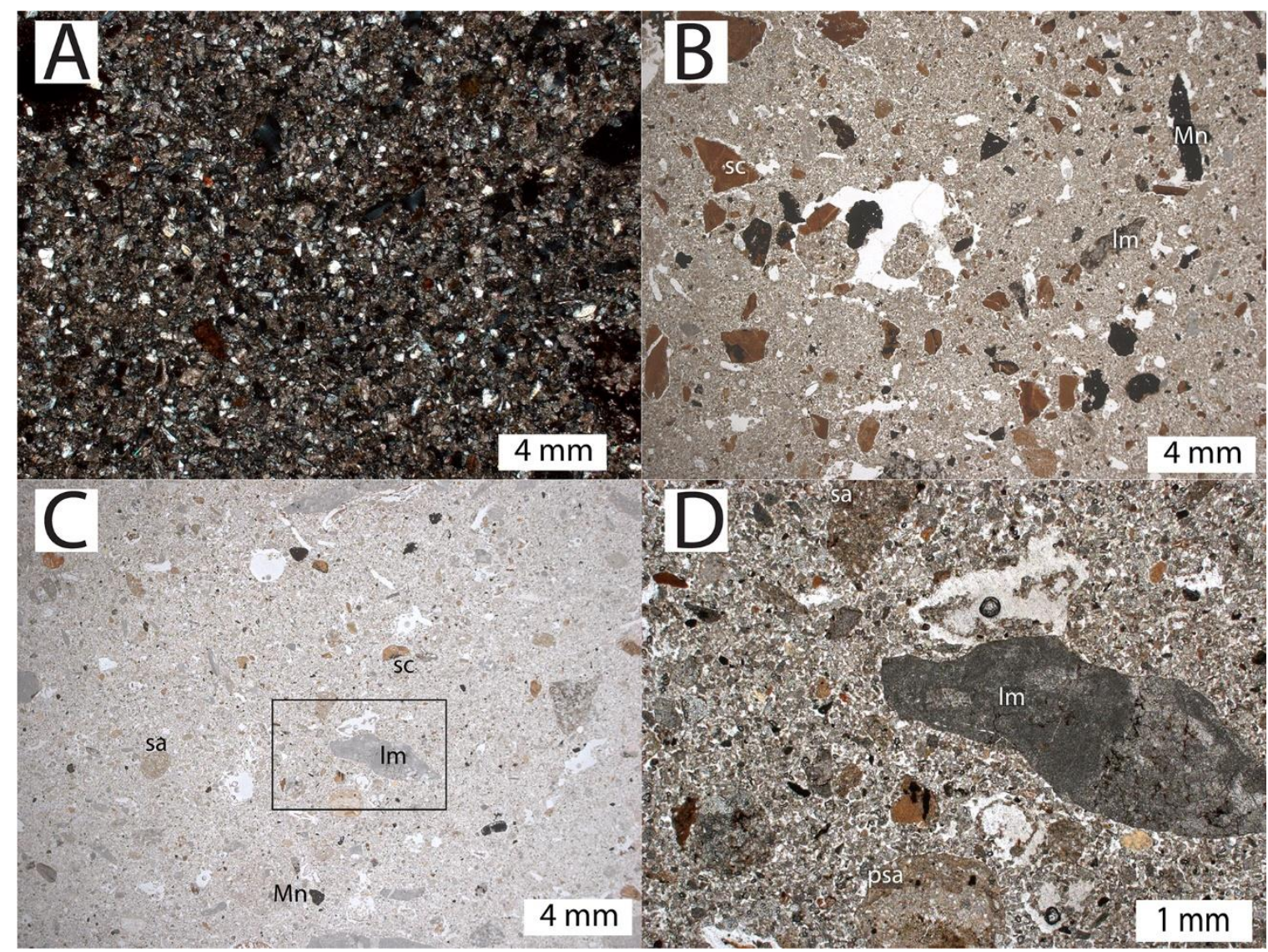


Fig. 9. Microphotographs from Ushozen 1 cave. A) Both MUs are comprised of randomly distributed, moderately to well sorted quartz and mica grains in a calcitic crystallitic micromass. This fabric is indicative of loess deposits; XPL. B) MU U3; closely packed texture dominated by sand-sized silty clay clasts and manganese oxide nodules; PPL. C) MU U2; lower abundance of coarse aggregates and smaller grain size result in a more open texture; PPL. D) Higher magnification picture from the area corresponding to the black frame in Fig. 9C. The presence of sand-sized rounded soil aggregates, some of which are phosphatized (see also Fig. 14B), demonstrate variability in post-depositional phosphatization.; PPL. Abbreviations used in the microphotographs: limestone clast $(\operatorname{Im})$, silty clay clasts $(\mathrm{sc})$, manganese oxide $(\mathrm{Mn})$, soil aggregate (sa), phosphatized soil aggregate (psa).

\subsection{Aqtogai 1}

The Aqtogai 1 cave lies on the right bank of the Shabaqty river, about 10km southeast of the Janatas town, Jambyl region, at the eastern part of the Lesser Qaratau. It is formed on Middle Ordovician limestone, at an uplifted and highly-deformed mountain front bounded by the Greater Qaratau Fault structure (Allen, Alsop, \& Zhemchuzhnikov, 2001, p. 89).

\subsubsection{Stratigraphy overview}

In Aqtogai 1, we expanded a test trench ( $3 \times 2 \mathrm{~m})$ partially excavated by Shunkov, Taimagambetov, $\&$ Kozlikin (2018) at the back of the cave exposing a stratigraphic sequence of about $2.5 \mathrm{~m}$ without reaching the bedrock. Penetrometer tests at the base of our test-pit demonstrated at least one meter of additional unexcavated sediments. The excavated deposits dip uniformly towards the entrance of the cave but vary significantly in the abundance of coarse clasts. The lower half of the sequence is generally more clast supported, with randomly distributed limestone fragments. In contrast, the upper part of the sequence is associated with matrix-supported layers that include calcite and clay nodules, and scarce limestone clasts. The topmost deposits (grouped as LU A1) consist of organic-rich and humified layers interbedded with ash lenses, resembling fumier/stabling deposits (Macphail et al., 2004; Brönnimann et al., 2017; ShahackGross, 2017). The cultural material that we recovered from the cave so far is of Holocene age, based on the presence of pottery, and was retrieved only from the upper part of the sequence. Our field 
observations largely agree with the stratigraphic descriptions provided by Shunkov, Taimagambetov, \& Kozlikin (2018).

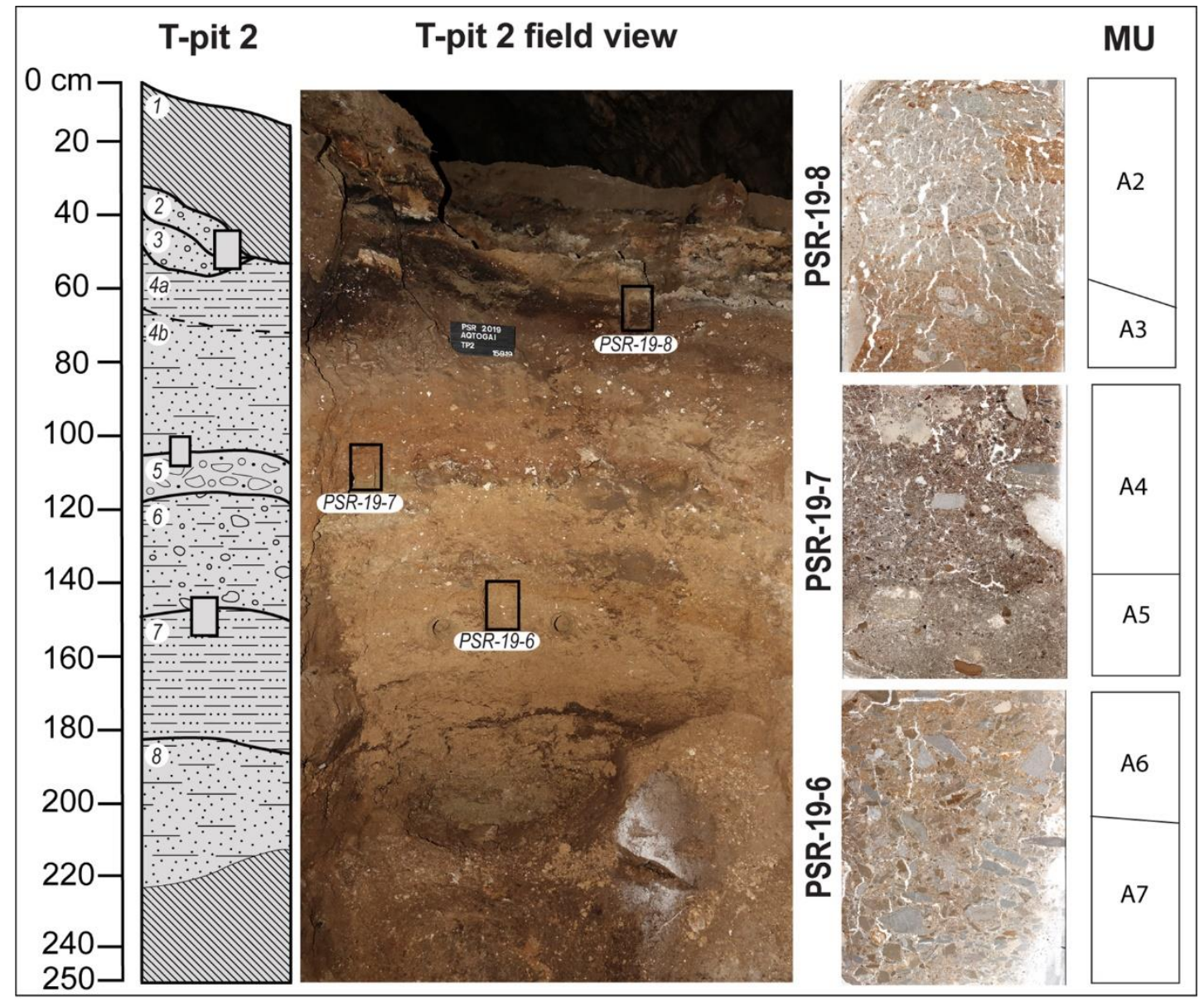

Fig. 10. Stratigraphy and micromorphology in Aqtogai 1 cave. Circled numbers indicate lithostratigraphic units: LU A1) heterogeneous sand and silt layers, disturbed; LU A2) clay loam; LU A3) clay loam; LU A4a) sandy silt loam; LU A4b) sandy clay; LU A5) sandy silt loam; LU A6) sandy silt loam; LU A7) sandy clay; LU A8) sandy clay, slumped. Black frames show the location of micromorphological samples accompanied by a scan of the thin section and MU classification.

\subsubsection{Micromorphology}

Micromorphology sample PSR-19-6 is classified into two MUs (A6 and A7) corresponding to the contact between LUs A6 and A7. Both MUs are clast supported and consist of autogenic geogenic materials with significant dung input (Fig. 11A). MU 7 has a higher abundance of oriented coarse components suggesting 
the operation of colluvial processes. Dung in both MUs demonstrates different stages of preservation based on the presence of complete dung pellets, humified dung aggregates, and phosphatized material still preserving few dung spherulites. The mixing of material in different states of preservation constitutes a proxy of sediment mixing.

The contact between LUs A4 and A5 is represented by MUs A4 and A5 recorded in micromorphology sample PSR-19-7. MU A5 has an open structure and includes gravel-sized dung pellets (Fig.11B). MU A4 (Fig. 11C) shows a high abundance of charcoal, dung, authigenic gypsum, and organics showing similarities to fumier/stabling deposits (Macphail et al., 2004; Brönnimann et al., 2017; Shahack-Gross, 2017). The presence of reworked geogenic cave materials (silty clay clasts, brecciated deposits), mixed with anthropogenic deposits demonstrates that different sedimentation cycles influenced the formation of MU A4.

MU A3 is a heterogeneous organic-rich deposit corresponding to LU A3. It consists of numerous rock fragments, phosphatic grains, endokarstic silty clay clasts, and dung pellets (Fig.11E and 14C). Dung exhibits again a varying degree of preservation like in MUs A6 and A7. The coarse material shows uniform dipping and orientation and is occasionally microlayered (Fig.11E). We hypothesize that the preferential arrangement of coarse components and the microlayering are a result of colluvial processes due to the absence of well-defined microlaminated structures that could indicate waterlain deposition (in contrast see Jetiotau; Fig.5A, B and Qyzyljartas; Fig.7B).

MU A2 is the only matrix-supported deposit recorded microscopically. In comparison to the other deposits, it is characterized by an abrupt lithological change, as it has a higher silt to very fine sand-sized quartz and mica component indicating increased aeolian sedimentation. It has also a higher abundance of exotic schist rock fragments, most probably trampled into the cave by animal/human movement. Organic matter is predominantly distributed in the form of discrete laminations (Fig.11E). Aeolian accumulation and the 
presence of organic laminations indicate a slow net rate of deposition and the preservation of original sedimentary structures.

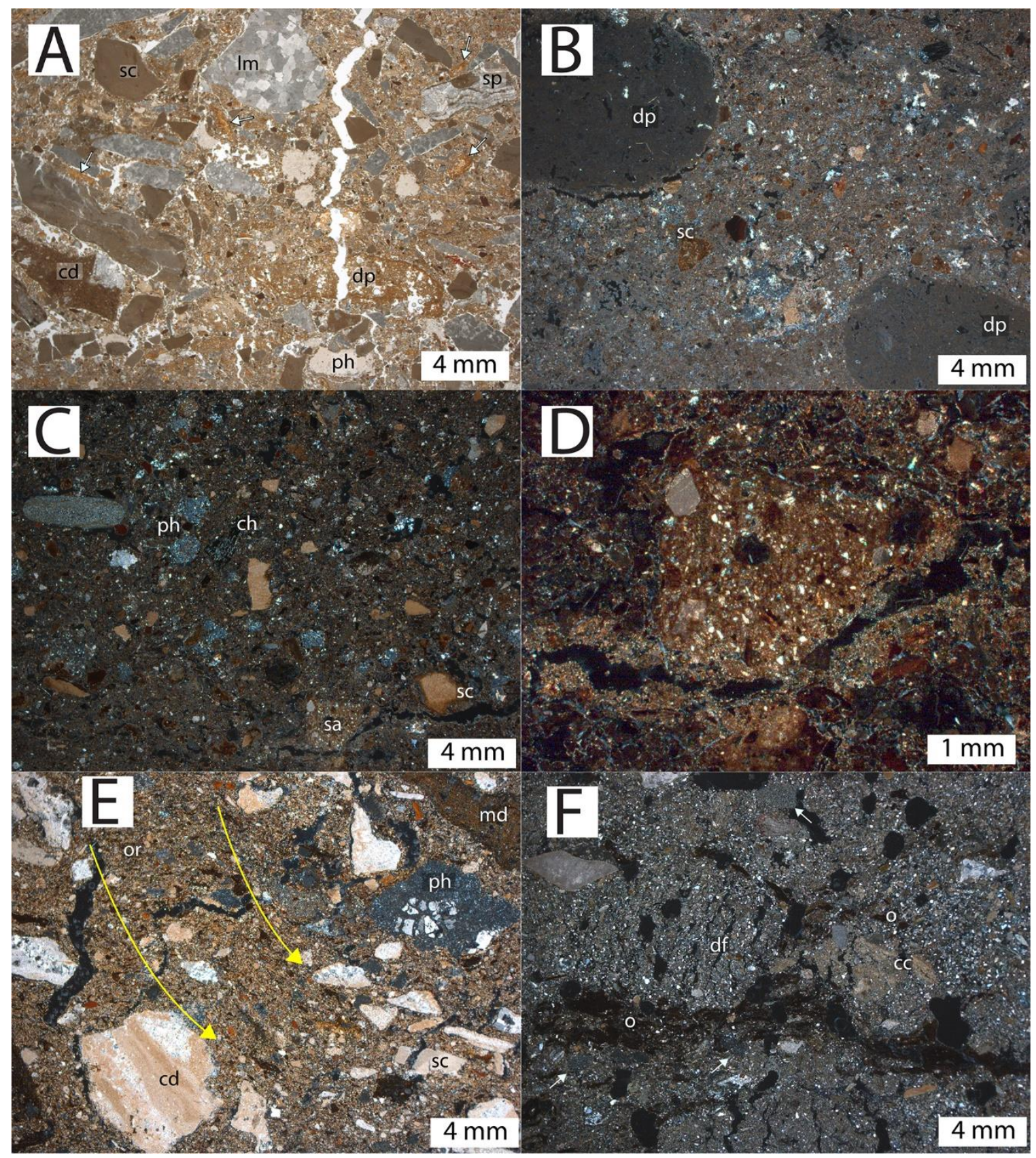

Fig. 11. Microphotographs from Aqtogai 1 cave. A) MU A7; randomly distributed coarse-sized limestone fragments (Im) and silty clay clasts (sc) mixed with dung pellets, degraded dung (arrows) and phosphatized material. Cemented deposits (cd) and a speleothem fragment (sp) are also present indicating the mixing of heterogeneous deposits; PPL. B) MU A5; gravel-sized dung pellets (dp) and few silty clay clasts (sc) embedded in an ashy matrix; XPL. C) MU A4; gravel-sized and comminuted charcoal (ch), sediment aggregates (sa) and common isotropic phosphatic aggregates; XPL. D) High magnification microphotograph of the soil- 
aggregate indicated in Fig. 11C. Note the high concentration of quartz silt and sand in the aggregate in comparison with the surrounding groundmass. XPL. E) MU A3; XPL. Limestone fragments, cemented deposits (cd) and silty clay clasts (sc) mixed with phosphatic aggregates (ph) and massive dung (md) remains in an organic rich (or) matrix. Coarse material is preferentially distributed and oriented along planes (here indicated by the yellow arrows); XPL. F) MU A2; calcitic crystallitic aggregates (cc) and phosphatized (white arrows) aggregates mixed with decalcified matrix (df). Notice organic laminations (o) in different parts of the deposits; XPL.

\subsection{Qaraungir 1}

Qaraungir 1 cave is located in the foothills of the Lesser Qaratau range, $30 \mathrm{~km}$ northeast of Shymkent in southern Kazakhstan. The inner part of the cave has been previously excavated by Taimagambetov \& Nokhrina (1998), with the oldest deposits dated to the Neolithic.

\subsubsection{Stratigraphy overview}

Building upon the work of (Taimagambetov \& Nokhrina, 1998), who documented Neolithic occupation in the interior of the cave, we decided to excavate outside of the dripline to assess the lateral distribution of archaeological deposits. Our test trench at Qaraungir 1 reached a maximum depth of $\sim 140 \mathrm{~cm}$, exposing scarce Holocene archaeological material throughout the sequence, but no dense cultural layers. The LU's have a silty clay to clayey loam texture, with a high frequency of coarse clasts especially in LU QA3 and towards the bottom of the trench. The shallow stratigraphy and the absence of cultural layers contrasts with the thick cultural sequences recorded inside the cave by (Taimagambetov \& Nokhrina, 1998). Therefore, Qaraungir 1 is the only surveyed cave where we have enough data to explore spatially diverse formation processes. Additionally, Qaraungir 1 is one of the few caves located in a down-slope position, providing an opportunity to study processes that may not be active in caves located in areas of higher topographic relief. 


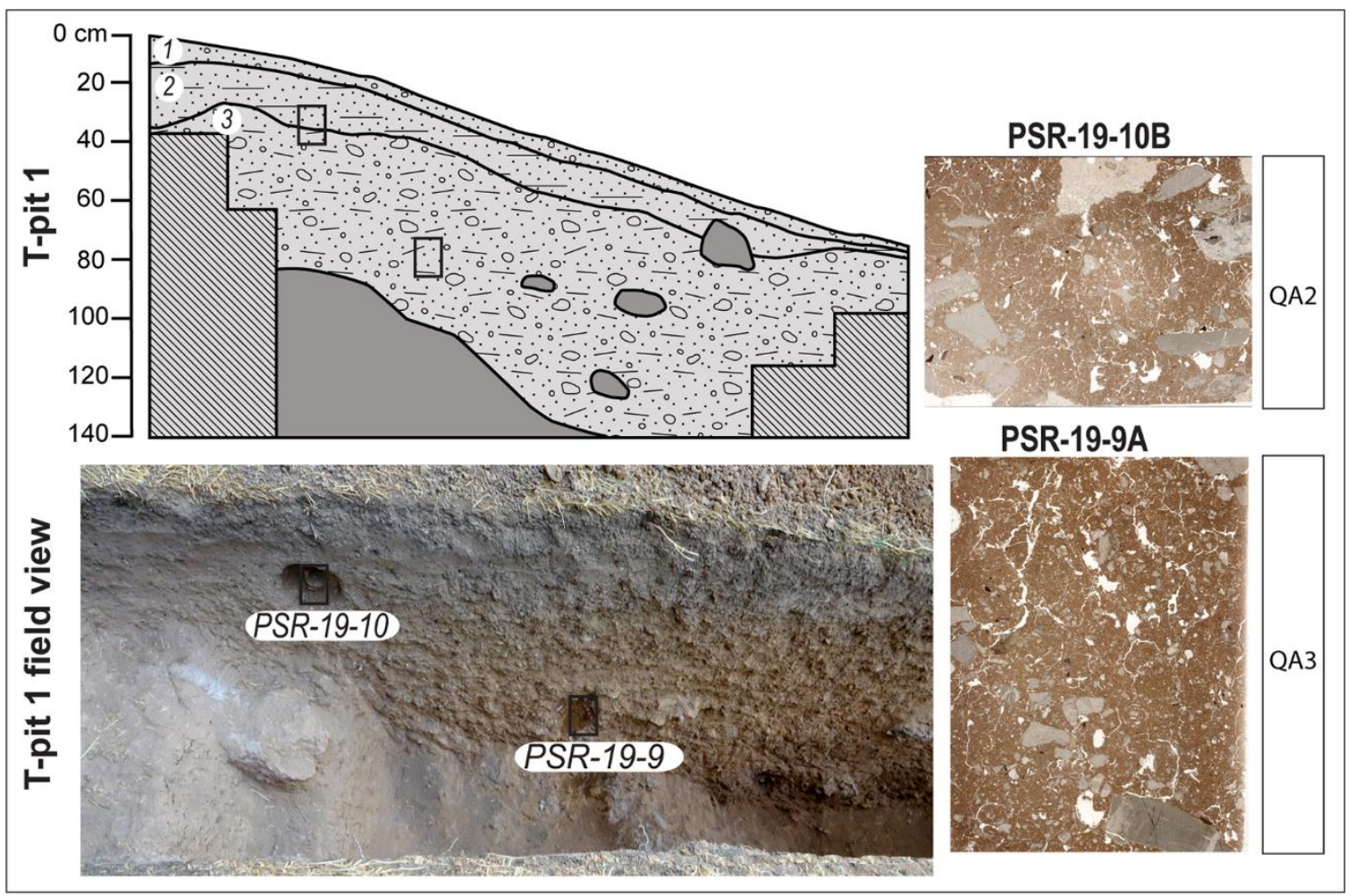

Fig. 12. Stratigraphy and micromorphology in Qaraungir 1 cave. Circled numbers indicate lithostratigraphic units: LU QA1) sandy loam; LU QA2) sandy silt loam; LU QA3) sandy clay loam. Black frames show the location of micromorphological samples accompanied by a scan of the thin section and MU classification.

\subsubsection{Micromorphology}

MU QA3 and QA2 are both clast-supported deposits that consist of various geogenic and biogenic components (Fig. 13). Although Qaraungir 1 is located in a downslope position, we did not observe significant soil input. The micromass fraction in both samples consists of silt-sized quartz, mica, and calcite indicating an aeolian source. Coarse clasts in both MUs are dipping down, following the inclination of the slope (Fig. 13A). Mobilization of cave material downslope is also evident by the presence of fabric hypocoatings around the coarse grains (Fig. 13B). The development of phosphatic rinds around limestone clasts confirms that this material was originally deposited in the cave (Fig. 14D). Despite the downslope movement, differences in the sorting of coarse material in MU QA3 indicate the preservation of 
microlayering. The deposits at Aqtogai 1 are exceptional examples of colluvially reworked loess-like cave sediments and provide evidence for the presence of active erosional processes in Qaratau caves.

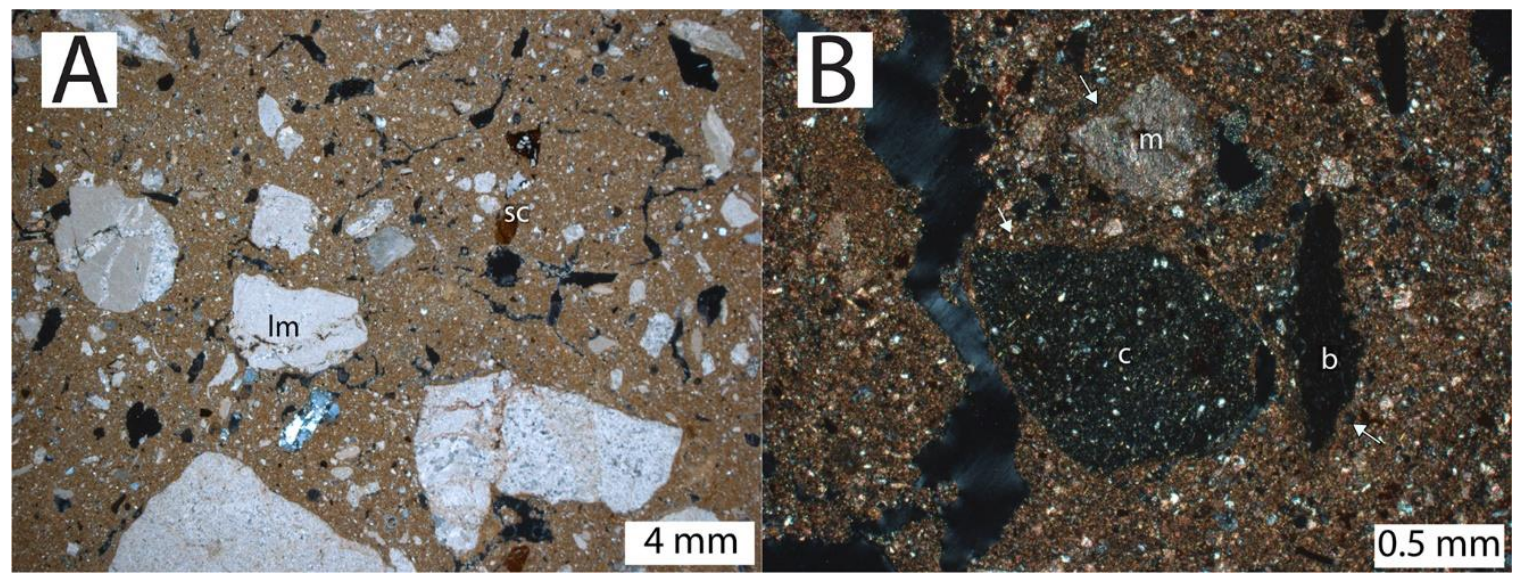

Fig. 13. Microphotographs from Qaraungir 1 cave. A) MU QA3; A comparison of the grain size and sorting between coarse components (e.g., limestone (Im) or silty clay (sc) clasts) between the lower left and top part of the microphotograph constitute an example of microlayering; XPL. B) MU QA2. Closer view of the calcitic crystallitic b-fabric, rich in quartz and mica, that characterizes the groundmass of both samples. Fabric hypocoatings (white arrows) around coarse clasts demonstrate reorientation of fabric by mechanical forces (Stoops, 2003,112).; XPL. Abbreviations used in the microphotographs: dung pellets (dp), phosphatized aggregates (ph), coprolite (c), marble (m), bones (b).

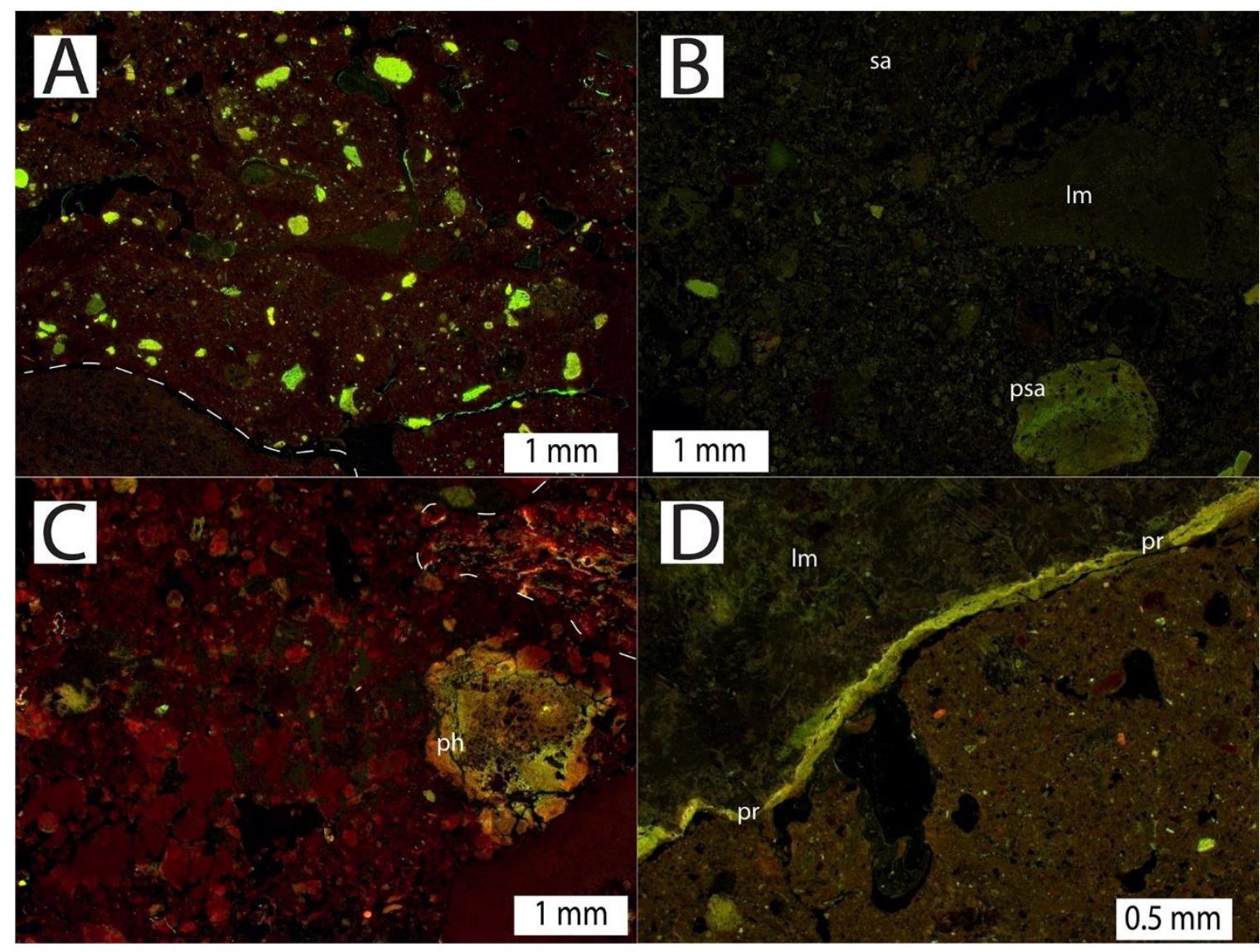


Fig. 14. Cave deposits seen under the fluorescent microscope. A) Jetiotau, MU J3-1. Mixed organic matrix rich in sand-sized phosphatic aggregates contrasting with laminated silty clay inclusions of endokarstic origin (white dashed line). B) Ushozen, MU U2. Similar field of view with Fig. 9D. Soil aggregates (sa) and limestone clasts ( $\mathrm{Im})$ mixed with isolated phosphatized soil aggregates (psa) in an organic poor deposit. C) Aqtogai 1, MU A3. Organic dominated matrix with phosphatic grains (ph) and dung pellets (white dashed line)1. D) Qaraungir 1, MU QA3. Phosphatic rind (pr) around limestone (Im) in an organic-rich matrix.

\section{Discussion}

Our survey and micromorphological data suggest that the accumulation and preservation of sediments varies among the Qaratau caves. Below we provide a discussion of the processes that influence the distribution of cave sediments in respect to the regional semi-arid context.

\subsection{Summary of site formation processes in the Qaratau caves}

Aeolian input leads to the formation of loess-like cave sediments that share common macroscopic characteristics across the cave sites. These sediments can be identified in the field based on pale color, silty texture and massive structure (see also Krajcarz et al., 2016). Based on our micromorphology analysis, we assume that these textural attributes result from similarities in the micromass, which is characterized by the high abundance of very fine sand to silt-sized quartz, mica grains and calcite. However, under the microscope, loess-like cave sediments also demonstrate a high degree of compositional variability, as they mix with a wide range of materials depending on the cave environment. Therefore, homogeneous windblown loess deposits were not observed in any of the caves, suggesting that the loess-like material found within the caves was likely reworked through a number of different processes.

In general, the loess-like cave sediments that we observed diverge from the typical loess deposits recorded in the region. Loess along the Kazakh Tian Shan piedmont is dominated by the remobilized silt of alluvial fans and plains, while the low content of sand-sized grains indicates that distal sources such as deserts and dunes have a minor impact on loess formation (Yue Li et al., 2020). This implies that local topography and 
proximity to sources significantly influence loess accumulation, since an important proportion of loess originates from proximal sources and topsoils (Yue Li et al., 2018; Sprafke et al., 2018). In comparison to the Tian Shan catchment, the Qaratau mountains are flanked by the deserts of the Qyzylqum and the Muyunkum, which could act as sources of short-distance sand transport under strong wind regimes. Based on this assumption, we hypothesize that the proximity of the Qaratau caves to sandy deserts could consequently explain the presence of the fine sand quartz and mica identified in most of our sediment samples. Further sedimentary analyses from cave and desert loess samples will test this hypothesis. Additionally, animal and human trampling or transport of plant material (Butzer, 1982, p. 80; Goldberg et al., 2009) could have transported soil aggregates with fine sand quartz into the caves (see Aqtogai 1, Ushozen 1). Overall, a combination of mainly geogenic and potentially anthropogenic processes results in loess-like cave sediments with a sandier and more polymodal distribution than the silt dominated piedmont loess deposits.

In contrast to grain shape, in this paper we demonstrated that grain orientation constitutes an especially useful tool for identifying post-depositional processes of loess-like cave sediments. Under the microscope, uniformly oriented mica particles may constitute a proxy of water reworking, or even form deformation features in a mass movement context. However, due to the homogeneity of the loess matrix, low energy reworking cannot always be observed in the micromass. Therefore, we suggest that the distribution and depositional history of the coarser sand-sized material that becomes mixed with loess is usually more helpful in documenting reworking in loess-like cave sediments.

Based on our survey results, the majority of the examined caves are hydrologically abandoned in the sense that they are decoupled from any major groundwater input (Sherwood and Goldberg, 2001). In consequence, their morphology indicates dry conditions and a stable microenvironment, which implies that sediments deposited in those contexts are largely unaltered by large scale reworking processes 
induced by active groundwater flow. While this may be true on a larger scale, our micromorphological analysis demonstrated that water action also impacted the development of cave sediments in the past. First, we recorded lithified silty clay clasts that are associated with the karstic phase of cave formation. These resistant old karst deposits remobilize throughout the sequence and constitute an important component of some cave deposits (Aqtogai 1, Jetiotau, Ushozen 1). Additionally, unlithified laminations of fine material (see Aqtogai 1) or channel deposits of coarse sand (see Qyzyljartas) demonstrate more recent water-driven processes. In this context, the frequent occurrence of low energy colluvial (Qaraungir 1, Aqtogai 1) or higher energy mass movement processes (Jetiotau) near the cave entrance also requires some degree of water saturation (Karkanas \& Goldberg, 2018). We hypothesize that regional orographic precipitation supplies the necessary water content driving the depositional processes described above. Because of higher relief, the Qaratau mountains and the greater Tian Shan mountain range are characterized by higher mean annual precipitation values and more frequent precipitation extreme events in comparison to other regions of Central Asia (Ma et al., 2020).

The depositional processes outlined above have diverse implications for the preservation of cave sequences. First of all, the thick aeolian deposits demonstrate that there are extensive periods of time where stable conditions enabled the settling of loess into the caves. Cave surfaces must have been exposed for a significant amount of time based also on the high content of phosphatized and calcified material (Miller, 2015; Barbieri et al., 2018). Except from phosphatization, diagenetic processes are mainly linked to the formation of authigenic gypsum, indicating mostly dry conditions. The absence of intensive diagenetic processes demonstrates that the Qaratau caves show good potential for the preservation of organic materials. In this regard, the case study from Aqtogai 1 demonstrates that the high frequency of organic materials is of highly importance for the build-up of thick cave sequences.

\subsection{Investigating cave erosion by combining field survey and micromorphology}


Understanding the processes that accumulate or remove cave sediments in Kazakhstan is a major challenge since most of the surveyed caves and rockshelters did not contain any sediments. In this regard, field survey provided minimum evidence for the erosion of sediments in individual caves. Potentially older cave surfaces, identified by the presence of remnant flowstone crusts, were recorded only in a handful of caves (Fig. 15A). The limited occurrence and spatial extent of flowstone surfaces, in parallel with the complete absence of sediment pockets provide no evidence for the presence of remnant deposits and cave floors in the surveyed features. In addition, evidence for ongoing sediment erosion is also minimal. Active erosional processes were recorded only in Nazugum rockshelter (lovita et al., 2020), where we documented water channels washing out parts of the sequence (Fig. 15B).

Generally, traces of erosion are more frequently related to processes affecting the exterior of karst features. In Qaratau, semi-arid conditions hinder the development of thick soils, facilitating the formation of scree-mantled slopes and talus cones (Abrahams, Howard, \& Parsons, 1994). Based on the high frequency of these erosional landforms in the mountain foothills of the surveyed areas, we hypothesize that caves or cave sediments might have been eroded from the landscape. In this context, the caves and rockshelters that we surveyed are usually found in a mid-slope position (Cuthbertson et al., 2021), overlooking these erosional scree-slopes (e.g., Fig. 15C). The relative absence of karst features at the bottoms of slopes and valley systems may imply the erosion of pre-existing features or their masking by accumulated scree and loess. Furthermore, larger scale erosion has been sometimes also observed in the front part of the caves, triggered by breaks in the local topography (e.g., Fig. 15D). Lastly, structural indications such as the association of caves with fault-lines and the frequent occurrence of large-size rockfall in their interior (lovita et al., 2020), indicates that caves in Qaratau are also influenced by active tectonics. 
Overall, our field survey observations suggest that erosion of cave sediments in Kazakhstan seems to operate differently between the level of the site and the level of the landscape. On the site scale, cave environments seem to be relatively stable without a complex history of remnant flowstone surfaces, cemented deposits and erosive water action. High intensity water-induced processes such as channel erosion or cementation are more common in more humid and tropical climates (e.g. O'Connor et al., 2017) and appear to have less impact on the evolution of cave deposits in drier regions like Kazakhstan. However, on the landscape scale, our observations suggest that cave and rockshelter erosion in Kazakhstan is controlled by broader changes tied to landscape stability and the semi-arid geomorphological processes that form scree-mantled slopes.

Even though it is difficult to test if the caves that are now empty had sediment at some point in the past, some implications regarding the erosion of cave sediments have been provided by our micromorphological analysis. Erosion and redeposition of older deposits have been documented in the micromorphology samples from all the examined caves, suggesting that reworking of cave sediments is a common theme in the Qaratau mountains. High intensity processes such as mudflows or sheet-flows usually remobilize older sediments and materials within the caves forming indicative microstructures. The reworking of individual grains along different parts of the cave sequences, such as the endokarstic silty clay clasts recorded in Ushozen 1, indicate constant but lower intensity processes that do not produce specific microstructures. Moreover, the redeposition of cave materials from the interior of Qaraungir 1 towards the slope outside of the dripline, is an indication that colluvial processes also influence the preservation of deposits in the few caves that are associated with soil-mantled slopes. 


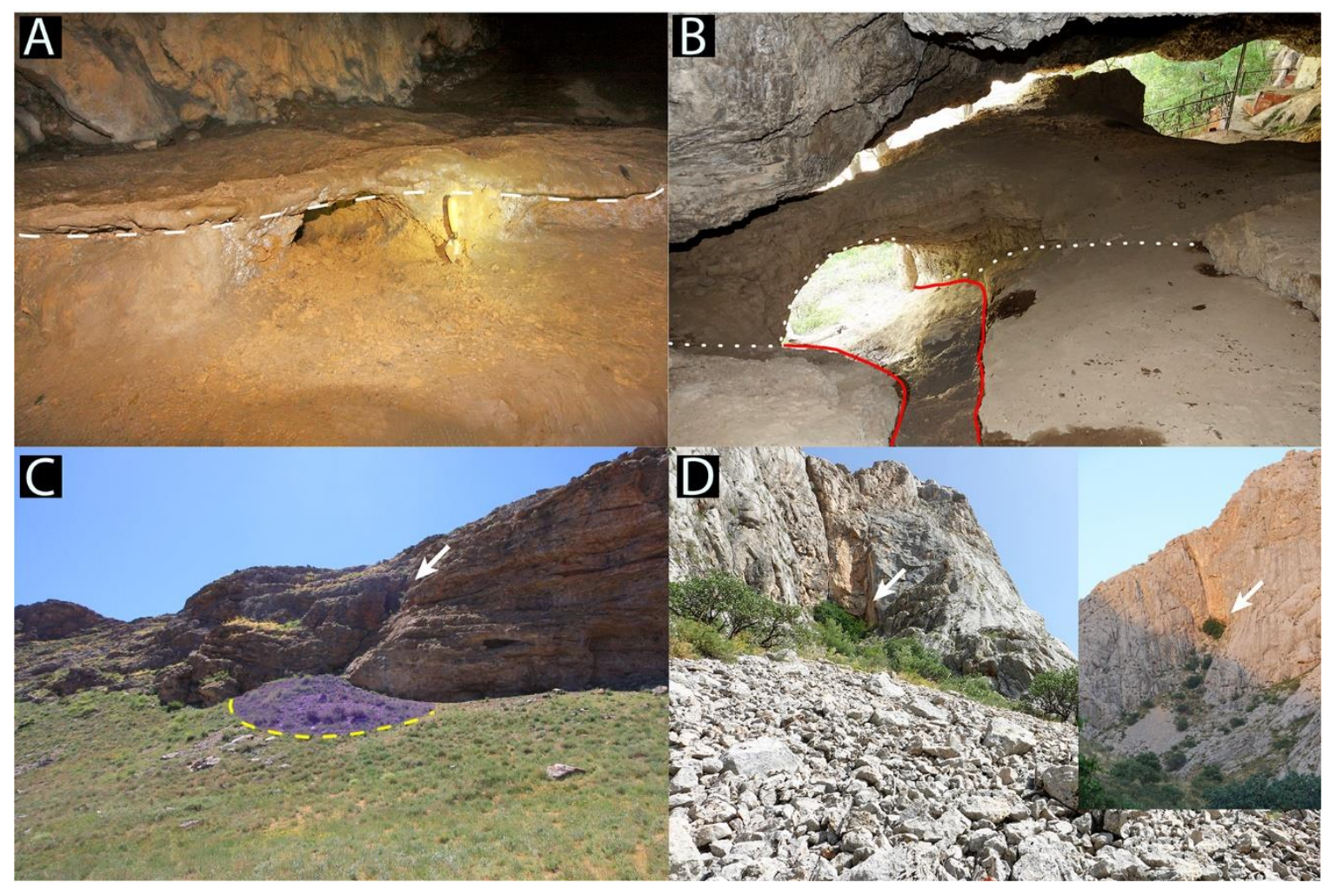

Figure 15. Isolated examples of eroded sediments in the interior of caves: A) Potentially truncated flowstone surface and underlying clay sediments in Jetiotau cave; the white dashed line marks the boundary between the two deposits. B) Erosional processes triggered by water action in Nazugum rockshelter. Black dashed lines outline a water channel, and white dotted lines outline the extent of sediment cover (note the presence of an erosional arch). The absence of sediments at the back of the feature contrary to the front indicates large-scale erosion. Examples of erosional pathways related to the adjacent topography: C) Talus cones (here opaquely masked and outlined by a yellow dashed line) in proximity to cave entrances (marked with white arrow) provide implications for near-entrance structural collapse. Qyzyljartas cave. D) Tuttybulaq 2 (marked here with a white arrow) provides an example of features located at a mid-slope elevation overlooking rock mantled slopes. Right; distant landscape view. Left; close-up of the moderately sorted scree down from the cave.

\subsection{The Qaratau caves in the context of Central Asian Palaeolithic and semi-arid zones}

Our survey in the Qaratau mountains has significant implications for the formation of the archaeological cave record in Central Asia. Despite the numerous caves that we recorded during our survey, only a few contain thick sediment sequences. A similar situation seems to occur in Uzbekistan and neighboring Mongolia, where recent surveys recorded only a few cave sites (Nishiaki et al., 2018, 2019; Vanwezer et al., 2021). The formation of cave sites requires human activity and a geomorphological setting that 
promotes the accumulation and preservation of sediments (Mentzer, 2017). The geological structure is important for the preservation of sediments and cave sites formed in rock strata that slope downwards tend to be eroded away under long time scales (Heydari, 2007). Besides rock type and structure, climate is the other major influence on the type of sediments deposited in a landscape and the pathways of its subsequent erosion (Burbank \& Pinter, 1999; Bull, 2009; Ke \& Zhang, 2021). However, the impact of climate on the evolution of cave sediments has been contextualized only for some environments in the geoarchaeological literature, such as Mediterranean and tropical (Woodward \& Goldberg, 2001; Morley, 2017). Central Asia and other arid or semi-arid settings have been largely neglected from the discussion of cave formation processes probably due to the lack of a group of well-documented sites. In this regard, exploring the formation processes of caves in semi-arid regions is particularly important for geoarchaeological research for two main reasons. First, arid and semi-arid regions that were traditionally considered as barriers of human movement now seem to have functioned as corridors of dispersal under more favorable climatic conditions (Osborne et al., 2008; Breeze et al., 2016; Li et al., 2019). By understanding the factors that govern the deposition and erosion of long cave sequences in these arid regions, we can assess preservation probability and better plan future surveys. Second, formation processes encountered in semi-arid climates, such as increased loess deposition, could be expected in cave sequences in other parts of the world where conditions were more arid in the past, for instance during glacial stages (Krajcarz et al., 2016; Barbieri et al., 2018). In this context, understanding the formation of loess-like cave sediments is especially important since archaeological caves with loess or generally aeolian deposits have a global distribution. Moreover, in areas like Kazakhstan, where well-developed speleothem records are absent and loess has a substantial distribution, loess in caves could constitute both a palaeoenvironmental archive (e.g., Pirson et al., 2006) and a chronostratigraphic tool for correlating caves sites, loess open-air sites and geological deposits.

An allochthonous sediment source is important for the filling of caves with sediment (lovita et al., 2020), and in Kazakhstan aeolian loess supplies the dominant proportion of allochthonous sediment accumulation. However, loess deposition is not uniform and is influenced by various parameters such as altitude, topography, and wind direction (Yun Li et al., 2015; Yue Li et al., 2020). The variability in the distribution of aeolian loess sediments together with the erosional processes presented in this paper could potentially explain the frequency of empty caves in Qaratau mountains. The limited soil cover in semi-arid areas (e.g., Fig. 15C, D) also hinders the redeposition of soil material in the caves through colluvial 
processes. This type of allochthonous colluvial sediment is important for the build-up of cave sequences in slightly more humid climates, such as dry-Mediterranean (Woodward \& Goldberg, 2001; Frumkin et al., 2016). The alteration of hot and cool conditions that are also present in semi-arid areas, facilitates the thermostatic weathering of the bedrock and leads to the accumulation of angular limestone debris in cave sequences (Cremaschi et al., 2015). Roof spall and remobilized karstic sediments constitute the dominant autochthonous geogenic deposit that we recorded in our survey. In cases of pseudokarstic caves, such as Qyzyljartas, the disintegration of non-carbonate bedrock into loose sediment will provide an extra source of autochthonous sediment accumulation (see also lovita et al., 2020). These autochthonous deposits mix with the aeolian component by colluvial and mass movement processes triggered inside the cave environment. Other processes, such as spring activity and sheetflow processes have only been recorded at Obi-Rakhmat (Mallol, Mentzer, \& Wrinn, 2009) and we hypothesize that they are relatively rare in Central Asian and semi-arid caves, since we also recorded them only in rare instances (e.g., Qyzyljartas and Nazugum).

The alteration of aeolian deposition and geogenic colluvial reworking seems to be a recurring pattern not only in caves of the semi-arid part of Central Asia (this work and Sel'ungur; Krivoshapkin et al., 2020) but also in the caves from the boreal and more humid Altai region. Available data from Strashnaya (Krivoshapkin et al., 2018, 2019), Chagyrskaya (Derevianko et al., 2018), and Ust'-Kanskaya (Lesage et al., 2020), suggest that some cave sequences in the Altai are punctuated by the accumulation of loess-like sediments and autochthonous colluvial reworking. However, Altai caves are also often characterized by cryogenic deformation features, most probably induced by the more boreal and humid local climatic conditions (Morley, 2017; Derevianko et al., 2018; Krivoshapkin et al., 2019). These features are postdepositional and constitute an additional agent of sediment mixing. Similar cryoturbation features have not yet been reported in the more arid southern Central Asia. Less intense post-depositional processes in the semi-arid parts of Central Asia would imply more secure cave contexts. 
Despite the more intense post-depositional processes, the Altai region has a much higher frequency of Palaeolithic cave sites in comparison to Central Asia. If we adopt a 'simplistic' climatic approach to the data, we could argue that the distribution of cave sites reflects solely diffferent climatic conditions. According to this approach, the Altai cluster reflects a more diachronic occupation favored by the overall better climatic conditions, while semi-arid Central Asia functions only as a corridor that witnesses substantial occupation only during phases of ameliorating climate. This approach however would not be valid based on the recent modeling data that suggest the presence and movement of hominin groups in the IAMC during both glacial and interglacial conditions (Glantz et al., 2018; Li et al., 2019). While the reasons for this preferential distribution of cave sites remain unclear, we believe that they also reflect variations in the processes that influence the formation of cave sediments and the stability of caves on the landscape. More evidence on regional site formation processes would greatly enhance the challenging task of correlating site distribution with human choice and dispersal routes.

\subsection{Methodological implications}

In this study, we demonstrated that micromorphological analysis could provide valuable information in archaeological surveys. By collecting qualitative data from several sites, we answered questions that often remain unaddressed by survey projects that focus primarily on the quantitative distribution of sites within the landscape. Occurrence and thickness of sediment cover, the origin of cave deposits, depositional processes, and post-depositional alterations are key site-specific parameters that could not have been explored by a purely landscape approach. Incorporating this information together allows us to examine the dominant processes that control the formation of the record but also demonstrates the degree of variation within a specific landscape. In the Qaratau example, we have demonstrated that even though loess is the main driver of allochthonous sediment accumulation, the way it gets reworked among the different caves varies greatly. In this regard, formation processes are not only influenced by site location 
but also by the site-specific depositional history. Other processes, such as anthropogenic input (e.g., at Aqtogai 1) or rare depositional processes (e.g., at Qyzyljartas) could form cave sequences that stand out from the rest of the dataset. Moreover, by combining macroscopic observations for the whole dataset together with site-specific analysis, we were able to address how representative our interpretations are in a broader sense. In this way, we supply the reader with data that are often omitted in archaeological survey publications. Even for sites of low archaeological potential, our micromorphological survey approach enables us to reconstruct cave life histories and model the potential formation processes that characterize our study area (see also Karkanas et al., 2021) and also to potentially examine factors of human absence in the landscape, as well as presence.

\section{Conclusions}

This paper provides a preliminary geoarchaeological context for our ongoing cave survey in the Qaratau mountains of South Kazakhstan (lovita et al., 2020). By combining model-led intensive field survey (Cuthbertson et al., 2021) with micromorphological analysis we assessed the distribution of cave sediments and prominent caves on the landscape, and demonstrated how cave formation processes are tied to the regional geomorphological and climatic factors. This work has implications for caves in similar semi-arid settings and provides a methodology for contextualizing survey data with a high-resolution analytical framework. Thus, it addresses themes that often remain unaddressed in the (geo) archaeological literature since well documented semi-arid caves sites are lacking, fieldwork projects often do not implement high-resolution site-specific analyses, and micromorphology studies often do not utilize a regional approach by focusing on a group of different cave sites.

Qaratau caves recorded different depositional styles, but loess-like cave deposits and reworking processes of varying intensity dominate the sediment sequences. Moreover, the depositional and erosional processes that characterize the surveyed caves are also associated with their landscape location. We hypothesize hillslope erosion might influence the removal of caves from the landscape, and in combination with loess cover might blanket caves found downslope. Future modeling work will assess these hypotheses tentatively. 
Overall, a new Denisova-type cave has not yet been found during our survey in the Qaratau mountains. Caves with the potential for Pleistocene sediments were inferred only from a couple of sites, and future excavation and dating are required to resolve the sedimentary record of these caves. Until now, only two Palaeolithic cave sites are known from Kazakhstan, even though the number of Palaeolithic open-air sites is gradually increasing (Anoikin et al., 2019; Ozherelyev, Dzhasybaev, \& Mamirov, 2019). However, the low frequency of Palaeolithic cave sites is a general characteristic of the caves found in the semi-arid regions of Central Asia and contrasts with the high clustering of Palaeolithic cave sites found in the more humid northern fringes of the Altai. This distribution cannot be explained only by climatic factors and in this paper, we present some of the formation processes that influence the deposition and erosion of sediments in Central Asia. We hypothesize that additional geological factors such as distribution and type of karst landscapes together with the subsistence strategies used by hominin groups in semi-arid environments shape the complex Central Asian Palaeolithic record. A methodology focusing on survey and highresolution analysis, similar to the one employed in this work, has the potential to unravel this record and provide the necessary data for further modeling research targeting human dispersals in the region.

\section{Acknowledgements}

A. Varis would like to thank Paul Goldberg, Boston, for his assistance in micromorphological analysis and research design and Peter Kühn, University of Tübingen, for his assistance with the fluorescent microscopy We would also like to thank P. Kritikakis, University of Tübingen, and Sabrina Save, Tessarscope Thin Section Slides, for the production of micromorphology thin sections. The PALAEOSILKROAD project conducted all field research under license No. 15008746 (12.05.2015) of the National Museum of the Republic of Kazakhstan based on the collaboration protocol between the Eberhard-Karls University of Tübingen and the National Museum. This project has received funding from the European Research Council (ERC) under the European Union's Horizon 2020 research and innovation programme (grant agreement $n^{\circ} 714842$; PALAEOSILKROAD project).

\section{References}

Abrahams, A. D., Howard, A. D., \& Parsons, A. J. (1994). Rock-Mantled Slopes. In A. D. Abrahams \& A. J. Parsons (Eds.), Geomorphology of Desert Environments (pp. 173-212). Dordrecht: Springer Netherlands. 
Albert, R. M., Berna, F., \& Goldberg, P. (2012). Insights on Neanderthal fire use at Kebara Cave (Israel) through high resolution study of prehistoric combustion features: Evidence from phytoliths and thin sections. Quaternary International, 247, 278-293.

Alexeiev, Bykadorov, V. A., Volozh, Yu. A., \& Sapozhnikov, R. B. (2017). Kinematic analysis of Jurassic grabens of soulthern Turgai and the role of the Mesozoic stage in the evolution of the Karatau-Talas-Ferghana strikeslip fault, Southern Kazakhstan and Tian Shan. Geotectonics, 51, 105-120.

Alexeiev, Cook, H. E., Buvtyshkin, V. M., \& Golub, L. Y. (2009). Structural evolution of the Ural-Tian Shan junction: A view from Karatau ridge, South Kazakhstan. Comptes Rendus Geoscience, 341, 287-297.

Allen, M. B., Alsop, G. I., \& Zhemchuzhnikov, V. G. (2001). Dome and basin refolding and transpressive inversion along the Karatau Fault System, southern Kazakstan. Journal of the Geological Society, 158, 83-95.

Alpysbaev, Kh. (1961). Otkrytie pamyatnikov drevnego i pozdnego paleolita Yuzhnogo Kazakhstana [Discovering of early and late Paleolithic sites in South Kazakhstan], 1, 128-138.

Anoikin, A. A., Pavlenok, G. D., Kharevich, V. M., Taimagambetov, Z. K., Shalagina, A. V., Gladyshev, S. A., Ulyanov, V. A., Duvanbekov, R. S., \& Shunkov, M. V. (2019). Ushbulak-A New Stratified Upper Paleolithic Site in Northeastern Kazakhstan. Archaeology, Ethnology \& Anthropology of Eurasia, 47, 16-29.

Asmerom, Y., Polyak, V. J., Wagner, J. D. M., \& Jonathan Patchett, P. (2018). Hominin expansion into Central Asia during the last interglacial. Earth and Planetary Science Letters, 494, 148-152.

Aubekerov, B. J. (1993). Stratigrafiya i paleogeografiya ravninnykh oblastey Kazakhstana v pozdnem pleistotsene i golotsene [Stratigraphy and paleogeography of the plain zones of Kazakhstan during the late Pleistocene and Holocene]. In A. A. Velichko (Ed.), Razvitiye landshaftov i klimata severnoy Evrazii. Pozdniy pleystotsengolotsen; elementy prognoza. Vypusk I. Regional'naya paleogeografiya [Development of landscape and climate of Northern Asia, late Pleistocene - Holocene; elements of prognosis. I. Regional Paleogeography] (pp. 88-89). Moscow: Nauka.

Barbieri, A., Leven, C., Toffolo, M. B., Hodgins, G. W. L., Kind, C.-J., Conard, N. J., \& Miller, C. E. (2018). Bridging prehistoric caves with buried landscapes in the Swabian Jura (southwestern Germany). Quaternary International, 485, 23-43. 
Baytanaev, B. A., Goryachev, A. A., Egorova, T. A., Ergeshbaev, A. A., Baytanaeva, A. B., \& Baytanaev, E. B. (2018). Arkheologicheskie issledovaniya v peschere Tuttybulaq-1 v $2018 \mathrm{~g}$. [Archaeological research in Tuttybulaq-1 cave in 2018]. Arkheologiya Kazakhstana, 1-2.

Baytanaev, B. A., Goryachev, A. A., Sarayev, V. V., \& Shayakhmetov, A. H. (2017). Arkheologicheskie issledovaniya pamyatnikov rannego zheleznogo veka v predgor'yakh Karatau i u severnykh sklonov khrebta Karzhantau [Archaeological researches of the Early Iron Age monuments in the foothills of Karatau and northern slopes of Karzhantau ridge]. Proceedings of the National Academy of Sciences of the Republic of Kazakhstan, 1, 143159.

Beeton, T. A., Glantz, M. M., Trainer, A. K., Temirbekov, S. S., \& Reich, R. M. (2014). The fundamental hominin niche in late Pleistocene Central Asia: a preliminary refugium model. (B. Riddle, Ed.)Journal of Biogeography, 41, 95110.

Biske, Y., S. (2015). Geology and evolution of the Central Asian orogenic belt in Kazakhstan and the western Tianshan. In A. Kroner (Ed.), The Central Asian orogenic belt. Geology, evolution, tectonics and models. (pp. 6-49). Stuttgart: Borntrager Science Publishers.

Breeze, P. S., Groucutt, H. S., Drake, N. A., White, T. S., Jennings, R. P., \& Petraglia, M. D. (2016). Palaeohydrological corridors for hominin dispersals in the Middle East 250-70,000 years ago. Quaternary Science Reviews, 144, 155-185.

Brönnimann, D., Ismail-Meyer, K., Rentzel, P., Pümpin, C., \& Lisá, L. (2017). Excrements of Herbivores. In Archaeological Soil and Sediment Micromorphology (pp. 55-65). John Wiley \& Sons, Ltd.

Bull, W. B. (2009). Geomorphic Responses to Climatic Change. Caldwell, N.J.: The Blackburn Press.

Burbank, \& Pinter. (1999). Landscape evolution: the interactions of tectonics and surface processes. Basin Research, $11,1-6$

Burtman, V. S. (1980). Faults of Middle Asia. American Journal of Science, 280, 725-744.

Buslov, M. M., Kokh, D. A., \& De Grave, J. (2008). Mesozoic-Cenozoic tectonics and geodynamics of Altai, Tien Shan, and Northern Kazakhstan, from apatite fission-track data. Russian Geology and Geophysics, 49, 648-654.

Butzer, K. W. (1982). Archaeology as Human Ecology: Method and Theory for a Contextual Approach. Cambridge: Cambridge University Press. 
Chlachula, J. (2010). Pleistocene climate change, natural environments and Palaeolithic occupation of East Kazakhstan. Quaternary International, 220, 64-87.

Cook, H., E., Zhemchuzhnikov, V., G., Zempolich, W., G., Zhaimina, V., Ya., Buvtyshkin, V., M., Kotova, E., A., Golub, L., Ya., Zorin, A., Ye., Lehmann, P., J., Alexeiev, D., V., Giovanneli, A., Viaggi, M., Fretwell, N., Lapointe, P., \& Corboy, J., J. (2002). Devonian and Carboniferous platform facies in the Bolshoi Karatau, southern Kazakhstan: outcrop analogs for coeval carbonate oil and gas fields in the North Caspian basin, western Kazakhstan. In W. Zempolich G. \& H. Cook E. (Eds.), Palaeozoic Carbonates of the Commonwealth of Independent States (CIS): Subsurface Reservoirs and Outcrop Analogs (pp. 81-122).

Courty, Goldberg, P., \& Macphail, R. (1989). Soils and Micromorphology in Archaeology. Cambridge University Press. Cremaschi, M., Zerboni, A., Charpentier, V., Crassard, R., Isola, I., Regattieri, E., \& Zanchetta, G. (2015). Early-Middle Holocene environmental changes and pre-Neolithic human occupations as recorded in the cavities of Jebel Qara (Dhofar, southern Sultanate of Oman). Quaternary International, 382, 264-276.

Cuthbertson, P., Ullmann, T., Büdel, C., Varis, A., Namen, A., Seltmann, R., Reed, D., Taimagambetov, Z., \& lovita, R. (2021). Finding karstic caves and rockshelters in the Inner Asian mountain corridor using predictive modelling and field survey. PLOS ONE, 16, e0245170.

Derevianko, A. P., Agadjanian, A. K., Baryshnikov, G. Y., Dergacheva, M., Dupal, T., Malaeva, E., Markin, S. V., Molodin, V., Nikolaev, S., \& Orlova, L. (1998). Arkheologia, geologia i paleografia pleistotsena i golotsena Gornogo Altaya (Archaeology, geology and palaeogeography of the Pleistocene and Holocene of the Mountainous Altai). Novosibirsk: Izdatelstvo Instituta Arkheologii i Ethnografii Sibirskogo Otdelen.

Derevianko, A. P., Markin, S. V., Baryshnikov, G. Y., \& Fedeneva, I. K. (1995). Iskra Cave - a New Multilayered Site in the Piedmont Altai. In A Review of the Results of Field and Laboratory Studies by Archaeologists, Ethnographists and Anthropologists in Siberia and the Far East in 1993. (pp. 63-70). Novosibirsk: Institute of Archaeology and Ethnography SB RAS PRESS.

Derevianko, A. P., Markin, S. V., \& Shunkov, M. V. (2013). The Sibiryachikha Facies of the Middle Paleolithic of the Altai. Archaeology, Ethnology and Anthropology of Eurasia, 41, 89-103.

Derevianko, A. P., \& Petrin, V. T. (1989). Akeologiia Maloialomanskoi Peschery. In Karst Altae-Saianskoi Gornoi Oblasti i Sopredel'nykh Gornykh Stran (pp. 16-19). Barnaul: Nauka. 
Derevianko, A. P., Postnov, A. V., Rybin, E. P., Kuzmin, Y. V., \& Keates, S. G. (2005). The Pleistocene peopling of Siberia: A review of environmental and behavioral aspects. Bulletin of the Indo-Pacific Prehistory Association, 25, 5768.

Derevianko, Markin, S., Kolobova, K., Chabai, V., Rudaya, N., Viola, B., Buzhilova, A., Mednikova, M., Vasiliev, S., Zykin, V., Zykina, V., Zazhigin, V., Volvakh, A., Roberts, R., Jacobs, Z., \& Li, B. (2018). Multidisciplinary Studies of Chagyrskaya Cave - A Middle Paleolithic Site in Altai.

Derevianko, Markin, S. V., Zykin, V. S., Zykina, V. S., Zazhigin, V. S., Sizikova, A. O., Solotchina, E. P., Smolyaninova, L. G., \& Antipov, A. S. (2013). Chagyrskaya Cave:A Middle Paleolithic Site In The Altai. Archaeology, Ethnology and Anthropology of Eurasia, 41, 2-27.

Douka, K., Slon, V., Jacobs, Z., Ramsey, C. B., Shunkov, M. V., Derevianko, A. P., Mafessoni, F., Kozlikin, M. B., Li, B., Grün, R., Comeskey, D., Devièse, T., Brown, S., Viola, B., Kinsley, L., Buckley, M., Meyer, M., Roberts, R. G., Pääbo, S., Kelso, J., \& Higham, T. (2019). Age estimates for hominin fossils and the onset of the Upper Palaeolithic at Denisova Cave. Nature, 565, 640.

Fitzsimmons, K. E., lovita, R., Sprafke, T., Glantz, M., Talamo, S., Horton, K., Beeton, T., Alipova, S., Bekseitov, G., Ospanov, Y., Deom, J.-M., Sala, R., \& Taimagambetov, Z. (2017). A chronological framework connecting the early Upper Palaeolithic across the Central Asian piedmont. Journal of Human Evolution, 113, 107-126.

Frachetti, M. D. (2012). Multiregional Emergence of Mobile Pastoralism and Nonuniform Institutional Complexity across Eurasia. Current Anthropology, 53, 2-38.

Frumkin, A., Langford, B., Marder, O., \& Ullman, M. (2016). Paleolithic caves and hillslope processes in south-western Samaria, Israel: Environmental and archaeological implications. Quaternary International, 398, $246-258$.

Glantz, M. M., Suleimanov, R., Hughes, P., \& Schauber, A. (2003). Anghilak cave, Uzbekistan: documenting Neandertal occupation at the periphery. Antiquity, 77, 1-4.

Glantz, M., Viola, B., Wrinn, P., Chikisheva, T., Derevianko, A., Krivoshapkin, A., Islamov, U., Suleimanov, R., \& Ritzman, T. (2008). New hominin remains from Uzbekistan. Journal of Human Evolution, 55, 223-237.

Glantz, Van Arsdale, A., Temirbekov, S., \& Beeton, T. (2018). How to survive the glacial apocalypse: Hominin mobility strategies in late Pleistocene Central Asia. Quaternary International, 466, 82-92. 
Goebel, T. (2004). The Early Upper Palaeolithic of Siberia. In P. J. Brantingham, S. L. Kuhn, \& K. W. Kerry (Eds.), The Early Upper Palaeolithic Beyond Western Europe (pp. 162-195). Berkeley-Los Angeles-London: University of California Press.

Gokhman, I. Y. (1957). The "Peshchera" Paleolithic site on the Bukhtarma river [Paleoliticheskaya stoyanka «Peshchera» na Bukhtarme]. Kratkie soobshcheniya o dokladakh i polevykh issledovaniya Instituta istorii material'noy kul'tury AN SSR [Short communications of reports and field investigations of the Institute for the History of Material Culture of the Academy of Science of the USSR], 67, 54-58.

Goldberg, P., Berna, F., \& Chazan, M. (2015). Deposition and Diagenesis in the Earlier Stone Age of Wonderwerk Cave, Excavation 1, South Africa. African Archaeological Review, 32, 613-643.

Goldberg, P., McPherron, S. J. P., Dibble, H. L., \& Sandgathe, D. M. (2018). Stratigraphy, Deposits, and Site Formation. In H. L. Dibble, S. J. P. McPherron, P. Goldberg, \& D. M. Sandgathe (Eds.), The Middle Paleolithic Site of Pech de l’Azé IV (pp. 21-74). Cham: Springer International Publishing.

Goldberg, P., Miller, C. E., Schiegl, S., Ligouis, B., Berna, F., Conard, N. J., \& Wadley, L. (2009). Bedding, hearths, and site maintenance in the Middle Stone Age of Sibudu Cave, KwaZulu-Natal, South Africa. Archaeological and Anthropological Sciences, 1, 95-122.

Grigoriev, F. P., \& Volkov, B. A. (1998). Novye materialy o peshchere Ushbas [New materials from Ushbas Cave]. Vestnik Universiteta Yassavi, 1, 68-75.

Haaland, M. M., Czechowski, M., Carpentier, F., Lejay, M., \& Vandermeulen, B. (2019). Documenting archaeological thin sections in high-resolution: A comparison of methods and discussion of applications. Geoarchaeology, 34, 100-114.

Heydari, S. (2007). The impact of geology and geomorphology on cave and rockshelter archaeological site formation, preservation, and distribution in the Zagros mountains of Iran. Geoarchaeology, 22, 653-669.

Iovita, R., Varis, A., Namen, A., Cuthbertson, P., Taimagambetov, Z., \& Miller, C. E. (2020). In search of a Paleolithic Silk Road in Kazakhstan. Quaternary International, 559, 119-132.

Karkanas, P. (2019). Microscopic deformation structures in archaeological contexts. Geoarchaeology, 34, 15-29. 
Karkanas, P., \& Goldberg, P. (2010). Site formation processes at Pinnacle Point Cave 13B (Mossel Bay, Western Cape Province, South Africa): resolving stratigraphic and depositional complexities with micromorphology. Journal of Human Evolution, 59, 256-273.

Karkanas, P., \& Goldberg, P. (2018). Reconstructing Archaeological Sites: Understanding the Geoarchaeological Matrix. Hoboken, NJ,USA: Wiley-Blackwell.

Karkanas, P., Marean, C., Bar-Matthews, M., Jacobs, Z., Fisher, E., \& Braun, K. (2021). Cave life histories of nonanthropogenic sediments help us understand associated archaeological contexts. Quaternary Research, 99, 270-289.

Ke, Q., \& Zhang, K. (2021). Patterns of runoff and erosion on bare slopes in different climate zones. CATENA, 198, 105069.

Kirscher, U., Zwing, A., Alexeiev, D. V., Echtler, H. P., \& Bachtadse, V. (2013). Paleomagnetism of Paleozoic sedimentary rocks from the Karatau Range, Southern Kazakhstan: Multiple remagnetization events correlate with phases of deformation. Journal of Geophysical Research: Solid Earth, 118, 3871-3885.

Krajcarz, M. T., Cyrek, K., Krajcarz, M., Mroczek, P., Sudoł, M., Szymanek, M., Tomek, T., \& Madeyska, T. (2016). Loess in a cave: Lithostratigraphic and correlative value of loess and loess-like layers in caves from the KrakówCzęstochowa Upland (Poland). Quaternary International, 399, 13-30.

Krause, J., Fu, Q., Good, J. M., Viola, B., Shunkov, M. V., Derevianko, A. P., \& Pääbo, S. (2010). The complete mitochondrial DNA genome of an unknown hominin from southern Siberia. Nature, 464, 894-897.

Krivoshapkin, A. I., Anoikin, A. A., \& Brantingham, P. J. (2007). The lithic industry of Obi-Rakhmat Grotto, Uzbekistan. Bulletin of the Indo-Pacific Prehistory Association, 26, 5-19.

Krivoshapkin, Krajcarz, M., T., Shalagina, A., V., Krajcarz, M., Kharevich, V. M., \& Chistyakov, P. V. (2019). Field Research in Strashnaya Cave (Northwestern Altai) in 2019: New Data on the Stratigraphy. Problems of Archaeology, Ethnography, Anthropology of Siberia and Neighboring Territories, XXV, 143-149 (in Russ.).

Krivoshapkin, Shalagina, A., Baumann, M., Shnaider, S., \& Kolobova, K. (2018). Between Denisovans and Neanderthals: Strashnaya Cave in the Altai Mountains. Antiquity, 92, 1-7. 
Krivoshapkin, Viola, B., Chargynov, T., Krajcarz, M. T., Krajcarz, M., Fedorowicz, S., Shnaider, S., \& Kolobova, K. (2020). Middle Paleolithic variability in Central Asia: Lithic assemblage of Sel'Ungur cave. Quaternary International, $535,88-103$.

Kuzmin, Y. V., \& Orlova, L. A. (1998). Radiocarbon Chronology of the Siberian Paleolithic. Journal of World Prehistory, 12, 1-53.

Lesage, C., Postnov, A. V., Krivoshapkin, A. I., \& Jaubert, J. (2020). Levallois reduction sequences in Altai: A view from the study of Ust'-Kanskaya Cave (Gorny-Altai, Russia). Quaternary International, 535, 104-116.

Li, Vanwezer, N., Boivin, N., Gao, X., Ott, F., Petraglia, M., \& Roberts, P. (2019). Heading north: Late Pleistocene environments and human dispersals in central and eastern Asia. PLOS ONE, 14, e0216433.

Li, Yue, Song, Y., Fitzsimmons, K. E., Chen, X., Prud'homme, C., \& Zong, X. (2020). Origin of loess deposits in the North Tian Shan piedmont, Central Asia. Palaeogeography, Palaeoclimatology, Palaeoecology, 559, 109972.

Li, Yue, Song, Y., Fitzsimmons, K. E., Chen, X., Wang, Q., Sun, H., \& Zhang, Z. (2018). New evidence for the provenance and formation of loess deposits in the Ili River Basin, Arid Central Asia. Aeolian Research, 35, 1-8.

Li, Yun, Song, Y., Yan, L., Chen, T., \& An, Z. (2015). Timing and Spatial Distribution of Loess in Xinjiang, NW China. PLOS ONE, 10, e0125492.

Ma, Q., Zhang, J., Game, A. T., Chang, Y., \& Li, S. (2020). Spatiotemporal variability of summer precipitation and precipitation extremes and associated large-scale mechanisms in Central Asia during 1979-2018. Journal of Hydrology X, 8, 100061.

Macphail, R. I. (1999). Sediment micromorphology. In M. B. Roberts \& S. A. Parfin (Eds.), Boxgrove: A Middle Pleistocene Hominid site at Eartham Quarry, Boxgrove, West Sussex. (pp. 118-148). London: English Heritage. Macphail, R. I. (2014). Archaeological Soil Micromorphology. In C. Smith (Ed.), Encyclopedia of Global Archaeology (pp. 356-364). New York, NY: Springer New York.

Macphail, R. I., Cruise, G. M., Allen, M. J., Linderholm, J., \& Reynolds, P. (2004). Archaeological soil and pollen analysis of experimental floor deposits; with special reference to Butser Ancient Farm, Hampshire, UK. Journal of Archaeological Science, 31, 175-191.

Mallol, C., Mentzer, S. M., \& Wrinn, P. J. (2009). A micromorphological and mineralogical study of site formation processes at the late Pleistocene site of Obi-Rakhmat, Uzbekistan. Geoarchaeology, 24, 548-575. 
Markin, S. V. (2019). Paleolithic Assemblages of the Sartan Glacial Period in the Northwestern Altai (Vol. 25, pp. 150156). Novosibirsk: Institute of Archaeology and Ethnography Press.

Markin, S. V., \& Antipov, A. S. (2012). The Iskra cave as the site illustrating the terminal upper Paleolithic in the northwestern Altai. Vestnik NGU., 11.

Mentzer, S. M. (2014). Microarchaeological Approaches to the Identification and Interpretation of Combustion Features in Prehistoric Archaeological Sites. Journal of Archaeological Method and Theory, 21, 616-668.

Mentzer, S. M. (2017). Rockshelter Settings. In A. S. Gilbert (Ed.), Encyclopedia of Geoarchaeology (pp. 725-743). Dordrecht: Springer Netherlands.

Milek, K. B., \& Roberts, H. M. (2013). Integrated geoarchaeological methods for the determination of site activity areas: a study of a Viking Age house in Reykjavik, Iceland. Journal of Archaeological Science, 40, 1845-1865.

Miller, C. E. (2015). A tale of two Swabian caves: geoarchaeological investigations at Hohle Fels and Geissenklösterle. Tübingen: Kerns Verlag.

Morley, M. W. (2017). The geoarchaeology of hominin dispersals to and from tropical Southeast Asia: A review and prognosis. Journal of Archaeological Science, 77, 78-93.

Morley, M. W., Goldberg, P., Uliyanov, V. A., Kozlikin, M. B., Shunkov, M. V., Derevianko, A. P., Jacobs, Z., \& Roberts, R. G. (2019). Hominin and animal activities in the microstratigraphic record from Denisova Cave (Altai Mountains, Russia). Scientific Reports, 9, 1-12.

Movius, H. L. (1953). Palaeolithic and Mesolithic Sites in Soviet Central Asia. Proceedings of the American Philosophical Society, $97,383-421$.

Mücher, H. J., \& Ploey, J. D. (1977). Experimental and micromorphological investigation of erosion and redeposition of loess by water. Earth Surface Processes, 2, 117-124.

Nicosia, C., \& Stoops, G. (Eds.). (2017). Archaeological Soil and Sediment Micromorphology. Chichester, UK: John Wiley \& Sons, Ltd.

Nishiaki, Y., Aripdjanov, O., Rajabov, A., Sayfullayev, B., Nakata, H., Arai, S., \& Akashi, C. (2018). Prehistoric caves and rockshelters in the Machay Valley, Surkhandarya, South Uzbekistan. al-Rāfidān, 39, 31-41. 
Nishiaki, Y., Aripdjanov, O., Sayfullayev, B., Engeshed, O., Grodeeva, E., Nakata, H., Arai, S., Noguchi, A., \& Suleymanov, R. (2019). Prehistoric caves and rockshelters in the Machay Valley, Surkhandarya, South Uzbekistan (II). alRāfidān, 40, 9-18.

O’Connor, S., Barham, A., Aplin, K., \& Maloney, T. (2017). Cave stratigraphies and cave breccias: Implications for sediment accumulation and removal models and interpreting the record of human occupation. Journal of Archaeological Science, 77, 143-159.

Okladnikov, A. P. (1940a). Amir-Temir, Novyi pamiatnik kamennogo veka v gorakh Baisun-Tau (Uzbekistan). AmirTemir, a new site of the stone age in the Baysun-Tau mountains (Uzbekistan)]. Kratkie Soobshche- niia o Dokladakh i Polevykh Issledovaniakh, Instituita Istor. Mater. Kult, 67-79.

Okladnikov, A. P. (1940b). Issledovanie paleoliticheskoi peshchery Teshik-Tash (predvaritel'noe soobshchenie). [Investigation of the Palaeolithic Cave of Teshik-Tash (Preliminary communication).]. Trudy Uzbekistanskogo Filiala Adademii Nauk SSSR, Tashkent, seria 1, Istoriia i Arkheologia, 3-45.

Osborne, A. H., Vance, D., Rohling, E. J., Barton, N., Rogerson, M., \& Fello, N. (2008). A humid corridor across the Sahara for the migration of early modern humans out of Africa 120,000 years ago. Proceedings of the National Academy of Sciences, 105, 16444-16447.

Ozherelyev, D. V., Dzhasybaev, E. A., \& Mamirov, T. B. (2019). Pervye dannye o stratigrafii i kul'turnol atribucii mnogosloinnol stojanki verhnego paleolita Rahat (Jugo-Vostochny̆̌ Kazahstan) [First data on the stratigraphy and cultural attribution of the Upper Paleolithic site of Rakhat (Southeast Kazakhstan)]. Kratkie soobshcheniya instituta arkheologii RAN Moskva, 57-70.

Pirson, S., Haesaerts, P., Court-Picon, M., Damblon, F., Toussaint, M., Debenham, N., \& Draily, C. (2006). BELGIAN CAVE ENTRANCE AND ROCK-SHELTER SEQUENCES AS PALAEOENVIRONMENTAL DATA RECORDERS: THE EXAMPLE OF WALOU CAVE. Geologica Belgica.

Ranov, V. A., \& Davis, R. S. (1979). Toward a New Outline of the Soviet Central Asian Paleolithic. Current Anthropology, 20, 23.

Reed, D., Barr, W. A., \& Kappelman, J. (2018). An Open-Source Platform for Geospatial Data Integration in Paleoanthropology. In R. L. Anemone \& G. C. Conroy (Eds.), New Geospatial Approaches to the Anthropological Sciences (pp. 211-224). Albuquerqe: University of New Mexico Press. 
Reed, D., Barr, W. A., Mcpherron, S. P., Bobe, R., Geraads, D., Wynn, J. G., \& Alemseged, Z. (2015). Digital data collection in paleoanthropology. Evolutionary Anthropology: Issues, News, and Reviews, 24, 238-249.

Reich, D., Green, R. E., Kircher, M., Krause, J., Patterson, N., Durand, E. Y., Viola, B., Briggs, A. W., Stenzel, U., Johnson, P. L. F., Maricic, T., Good, J. M., Marques-Bonet, T., Alkan, C., Fu, Q., Mallick, S., Li, H., Meyer, M., Eichler, E. E., Stoneking, M., Richards, M., Talamo, S., Shunkov, M. V., Derevianko, A. P., Hublin, J.-J., Kelso, J., Slatkin, M., \& Pääbo, S. (2010). Genetic history of an archaic hominin group from Denisova Cave in Siberia. Nature, 468, 1053-1060.

Rudenko, S. I. (1961). The Ust'-Kanskaia Paleolithic Cave Site, Siberia. American Antiquity, 27, $203-215$.

Seltmann, R., Shatov, V., \& Yakubchuk, A. (2014). Mineral deposits database and thematic maps of Central Asia, scale 1:1 500 000, ArcGIS 10.1 package and Explanatory Notes: Centre for Russian and Central Eurasian Mineral Studies (CERCAMS). Natural History Museum, London, UK, 120.

Shahack-Gross, R. (2017). Animal Gathering Enclosures. In Archaeological Soil and Sediment Micromorphology (pp. 265-280). John Wiley \& Sons, Ltd.

Shunkov, M. V., Taimagambetov, Zh. K., \& Kozlikin, M. B. (2018). The 2018 Archaeological Survey in Southern Kazakhstan. Problems of Archaeology, Ethnography, Anthropology of Siberia and Neighboring Territories, 24, 190-193.

Slon, V., Mafessoni, F., Vernot, B., de Filippo, C., Grote, S., Viola, B., Hajdinjak, M., Peyrégne, S., Nagel, S., Brown, S., Douka, K., Higham, T., Kozlikin, M. B., Shunkov, M. V., Derevianko, A. P., Kelso, J., Meyer, M., Prüfer, K., \& Pääbo, S. (2018). The genome of the offspring of a Neanderthal mother and a Denisovan father. Nature, 561, 113-116.

Sprafke, T., Fitzsimmons, K. E., Grützner, C., Elliot, A., Marquer, L., \& Nigmatova, S. (2018). Reevaluation of Late Pleistocene loess profiles at Remizovka (Kazakhstan) indicates the significance of topography in evaluating terrestrial paleoclimate records. Quaternary Research, 89, 674-690.

Stoops, G. (2003). Guidelines for analysis and description of soil and regolith thin sections. Madison: Soil Science Soc. of America.

Taimagambetov, Zh., \& Nokhrina, T. I. (1998). Arheologicheskie kompleksy peshchery Karaungur (Yuzhnyi Kazahstan) [Archaeological complexes from Karaungur Cave (South Kazakhstan)]. Turkestan: Miras. 
Trifonov, V. G., Artyushkov, E. V., Dodonov, A. E., Bachmanov, D. M., Mikolaichuk, A. V., \& Vishnyakov, F. A. (2008). Pliocene-quaternary orogeny in the Central Tien Shan. Russian Geology and Geophysics, 49, 98-112.

Vanwezer, N., Breitenbach, S. F. M., Gázquez, F., Louys, J., Kononov, A., Sokol'nikov, D., Erdenedalai, A., Burguet-Coca, A., Picin, A., Cueva Temprana, A., Sánchez-Martínez, J., Taylor, W., Boivin, N., Jamsranjav, B., \& Petraglia, M. D. (2021). Archaeological and environmental cave records in the Gobi-Altai Mountains, Mongolia. Quaternary International, S1040618221001361.

Vishnyatsky, L. (1999). The Palaeolithic of Central Asia. Journal of World Prehistory, 69-122.

Windley, B. F., Alexeiev, D., Xiao, W., Kröner, A., \& Badarch, G. (2007). Tectonic models for accretion of the Central Asian Orogenic Belt. Journal of the Geological Society, 164, 31-47.

Woodward, J. C., \& Goldberg, P. (2001). The sedimentary records in Mediterranean rockshelters and caves: Archives of environmental change. Geoarchaeology, 16, 327-354.

Zwyns, N. (2012). Laminar technology and the onset of the Upper Paleolithic in the Altai, Siberia. Leiden: Leiden University Press. 